\title{
PRAVNI STATUS SUDIONIKA U KOMPLEKSNOM POSTUPKU OVRHE NA BRODU RADI NAPLATE NOVČANE TRAŽBINE
}

UDK: 347.79. (497.5)

DOI: $10.31141 /$ zrpfs.2020.57.138.1113

Stručni rad

Primljeno: 15. prosinca 2019.

\begin{abstract}
Specifične, kompleksne i problematične situacije koje se javljaju u postupku ovrhe na brodu radi naplate novčane tražbine zahtijevaju podrobniju analizu svih problematičnih pitanja.Takve situacije su odraz nedovoljno utvrđenih odredbi, odnosno nepostojećih odredbi koje je zakonodavac propustio utvrditi, a reguliraju ovakav postupak naplate tražbina. Intencija ovoga rada je unificirani i sustavni prikaz takve problematike kroz sve faze postupka. U provedbi ovrhe su evidentni složeni međusobni odnosi neposrednih sudionika na koje se odnose uzrok i posljedice postupka, te posrednih sudionika koji imaju neki pravni interes, pa na njih mogu (ali i ne moraju) utjecati posljedice postupka. Pri tome valja naglasiti da se sustavno iznose pravne dvojbe o statusu neposrednih i posrednih sudionika postupka, te problematika postupovnih radnji cjelokupnog postupka, a ne samo faze provedbe ovrhe na brodu. Svaka faza postupka je opterećena manjom ili većom problematikom, bez iznimke, od podnošenja prijedloga za ovrhu do naplate vjerovnika. Isto tako, mogući su slučajevi zlonamjernih raspoložbi s krajnjim ciljem da se obustavi ovrha i spriječi prodaja broda koji je predmet ovrhe. Zakonodavac je propustio kvalitetno utvrditi ovu materiju, pa rješenja nekih inozemnih pravnih sustava, koja se odnose na postupak ovrhe, mogu poslužiti kao putokaz u nadopuni postojećih odredbi Pomorskog zakonika.
\end{abstract}

Ključne riječi: kompleksnost ovrhe na brodu, neposredni sudionici postupka, posredni sudionici postupka, postupovne radnje, nepotpune odredbe

\section{UVOD}

Dio terminologije koji se koristi u naslovu rada - Kompleksan postupak ovrhe na brodu radi naplate novčane tražbine upućuje na široku, sustavnu i potpunu obradu cijeloga postupka ovrhe, te problematike koja prati postupak sukladno odredbama čl. 841. - 931. Pomorskog zakonika, NN br. 181/04, 76/07, 146/08, 61/11, 56/13, 26/15, 17/19 (dalje PZ). Postupak ovrhe, općenito, između ostalih i onaj na brodu, jest niz pravno uređenih i funkcionalnih radnji suda, stranaka i drugih sudionika postupka koje imaju za cilj prisilno ostvarenje ovrhovoditeljeve tražbine. Ovrha se provodi u situaciji u kojoj je u jednom prethodnom parničnom, izvanparničnom, kaznenom i upravnom postupku na nesumnjiv način ovršnom ispravom utvrđena ovrhovoditeljeva tražbina. Brod je stvar velike vrijednosti, pa se kao najraširenije 
i ekonomski najisplativije prijevozno sredstvo podvrgava knjižnom režimu evidentiranjem u upisnik brodova. ${ }^{1}$ Postoje razlozi koji dovode do potrebe da se brodovi vlastite državne pripadnosti evidentiraju u upisniku brodova, te se u stvarnopravnim raspolaganjima tretiraju kao nekretnine na kopnu i podvrgavaju knjižnom režimu. Prvenstveni razlog za takav upis jest povezanost prava vlasništva na brodu s pravom državne pripadnosti broda. $\mathrm{O}$ državnoj pripadnosti broda ovisi koji će pravni poredak biti mjerodavan u slučaju ovrhe na stranom brodu. Ovrhu određuju i provode trgovački sudovi nadležni za pomorske sporove. ${ }^{2}$ Ovrha na brodu specifičan je, kompleksan i problematičan pravni postupak. Specifičnost se očituje u imovinskopravnim karakteristikama broda kao pokretne, nepotrošene i sastavljene stvari. Kao pokretnina brod je mobilno plovilo namijenjeno plovidbi, s mogućnošću dolaska i odlaska na određenu lokaciju (luku). Brod je i nepotrošena stvar sa svrhom trajnog iskorištavanja, a sastavljena od mnogih samostalnih i nesamostalnih dijelova te pripadaka koji trajno služe upotrebi broda. Kompleksnost se očituje u nepredvidljivim i složenim odnosima između neposrednih i posrednih sudionika postupka ovrhe, kao i u većem broju postupovnih radnji koje je potrebno obaviti da bi se uspješno okončao postupak. Iz ovih razloga primjenjuju se odredbe mnogih grana prava: pomorskog, stvarnog, obveznog, sudskog, parničnog, izvanparničnog, a po potrebi i međunarodnog. U sudskoj praksi taj broj postupovnih radnji varira od jednog do drugog slučaja ovrhe i nije ih moguće unaprijed odrediti, zbog toga što se postupak može provoditi u različitim okolnostima i na brodovima različite državne pripadnosti. Uzrok problematičnosti i slabije efikasnosti postupka su nepotpune, čak i nepostojeće norme koje utvrđuju ovu materiju. Najveći propust zakonodavca, koji utječe na cijeli postupak jest nepostojanje knjižnog režima za pomorske privilegije. Prema čl. 214. st. 2. PZ-a za pravovaljanost pomorskog privilegija, koji kao stvarnopravni teret opterećuje brod, nije potreban upis u upisnik brodova. Ovaj stavak je u koliziji sa st. 1. istoga članka koji određuje da se pravo vlasništva i druga stvarna prava (dakle i privilegiji) mogu steći, prenijeti, ograničiti i ukinuti jedino upisom u odgovarajući upisnik brodova. Sukladno člancima 853. i 854. PZ-a, nakon podnesenog prijedloga za ovrhu nadležnom sudu i njegovim prihvaćanjem kroz doneseno rješenje o ovrsi, ovrha na brodu i brodu u gradnji provodi se zabilježbom ovrhe u upisnik brodova, utvrđivanjem vrijednosti broda, prodajom broda i naplatom ovrhovoditelja i vjerovnika iz iznosa dobivenog prodajom.

1 PZ u članku 5. t. 2. utvrđuje da brod, osim ratnog broda, jest plovni objekt namijenjen za plovidbu morem, čija je duljina trupa veća od 15 metara, ili je ovlašten prevoziti više od 12 putnika. Brod može biti putnički, teretni, tehnički plovni objekt, ribarski, javni ili znanstvenoistraživački. Točka 5. istog članka utvrđuje da je brod u gradnji brod koji se gradi od trenutka polaganja kobilice ili sličnog postupka gradnje, a upisan je u upisnik brodova kao brod u gradnji, do završetka gradnje i upisa u upisnik brodova kao brod. Postupak za upisivanje brodova u upisnik brodova reguliran je odredbama članaka 253. - 313. PZ-a.

2 Čl. 841. st. 6. PZ-a. 


\section{SUDIONICI I OSNOVNA NAČELA POSTUPKA OVRHE NA BRODU RADI NAPLATE NOVČANE TRAŽBINE}

Ovrha je sudski postupak koji je pokrenut kako bi se tražbina vjerovnika potpuno i konačno ostvarila. Sudionici postupka su fizičke ili pravne osobe koje imaju određeni pravni interes. Neposredni su sudionici oni na koje se odnose uzrok pokretanja i posljedice postupka, a to su ovrhovoditelj-vjerovnik i ovršenik-dužnik. Ovrhu na brodu mogu pokrenuti dva ili više ovrhovoditelja, a brod može biti opterećen s više tražbina vjerovnika. Posredni sudionici su oni na koje se mogu (ali i ne moraju) odnositi posljedice postupka. To su zapovjednik broda pod ovrhom, posada broda i čuvari broda kod određivanja privremene mjere zaustavljanja i čuvanja broda, eventualna treća osoba kao nadponuditelj, kupac broda i ostali vjerovnici koji se naplaćuju u postupku. Pokretanjem ovrhe pravni status neposrednih sudionika postupka postaje izuzetno težak zbog slabe ili nepostojeće normativne regulacije, najčešće predugog ovršnog postupka, te financijski neutvrđenih i nepovoljnih opterećenja koje moraju podnijeti. Odredbama čl. 865. PZ-a, ovrhovoditeljev pravni status potpuno je neizvjestan. Prvi dio odredbe st. 1. toga članka zahtijeva posebnu analizu, a utvrđuje da je ovrhovoditelj prethodno dužan snositi troškove provedbe ovrhe. Visinu troškova koji su mu odredbom određeni nije moguće unaprijed utvrditi, a mogu biti raznoliki i visoki. Po st. 2. toga članka sud može odrediti da ovrhovoditelj predujmi potrebnu svotu za namirenje troškova provedbe ovrhe. Nisu određeni kriteriji po kojima bi sud prisilio ovrhovoditelja da mora predujmiti određenu svotu, pa to stvara dodatnu nesigurnost i neizvjesnost ovrhovoditelju. Po st. 3. toga članka ovrhovoditelj mora položiti predujam u roku koji odredi sud po svojoj subjektivnoj odluci, ili će sud rješenjem obustaviti ovršni postupak. Ova je odredba u koliziji s načelom zaštite ovrhovoditelja koji bi bio onemogućen u naplati svoje nesporne tražbine zbog nastupa posebnih okolnosti. Takva bi okolnost mogla biti da ovrhovoditelj ne može položiti određeni predujam u zadanom (prekratkom) roku, jer trenutno nema dovoljno novčanih sredstava. Jasno je i logično da ovrhovoditelj, kao neposredni sudionik koji je pokrenuo ovrhu, mora podnijeti osnovne troškove postupka, ali pod jasno utvrđenim uvjetima i odredbama. Pravni status posrednih sudionika postupka može biti kompleksan i problematičan zbog različitih okolnosti i postupovnih radnji koje nije moguće unaprijed predvidjeti a mogu se pojaviti. Zakonske odredbe u slučaju pojave i ostvarenja takvih okolnosti nepotpune su ili potpuno neutvrđene. Tu se prvenstveno misli na određivanje privremene mjere zaustavljanja i čuvanja broda. Problematika može proizlaziti iz pravnog (radnog) odnosa brodara odnosno vlasnika broda-ovršenika, kao neposrednog sudionika, sa zapovjednikom i posadom broda (čuvarima broda), kao posrednim sudionicima u postupku ovrhe. Isto tako, treća osoba-nadponuditelj kao posredni sudionik postupka nalazi se u nedovoljno utvrđenom pravnom statusu. Moguće su i razne zlonamjerne raspoložbe kupca, te kupca i ovršenika, kojima je cilj spriječiti prisilnu prodaju broda. Nisu rijetki niti međusobni prijepori među ostalim vjerovnicima radi osporavanja postojanja tražbina, njihove visine iznosa i reda naplate. Postupak se mora odvijati u skladu s osnovnim načelima ovršnog prava: 
1. Načelo zakonitosti - određuje da se postupak provodi uz strogo poštovanje pravnih normi koje utvrđuju tu materiju uz podrednu primjenu normi drugih grana prava, ako to zahtijevaju specifične okolnosti postupka.

2. Načelo zaštite ovršenika - određuje da se u postupku treba paziti na dostojanstvo ovršenika, te na to da za njega ovrha bude što manje nepovoljna i u skladu s načelom zakonitosti.

3. Načelo zaštite ovrhovoditelja - određuje da se ovršenik ne može protiviti ovrsi, ako je ovrhovoditelj na temelju pravnog posla s ovršenikom stekao na nekoj stvari (brodu) založno ili slično pravo radi osiguranja tražbine čije prisilno ostvarenje traži.

4. Načelo dispozicije i oficijelnosti - određuje da se postupak pokreće podnošenjem prijedloga za ovrhu od strane ovrhovoditelja nadležnom trgovačkom sudu.

5. Načela saslušanja stranaka i traženja istine - određuju da postupak treba provesti bez odugovlačenja i sa što manje troškova. Stranke mogu ravnopravno isticati svoje zahtjeve i izjasniti se o zahtjevima i navodima suprotne stranke. Stranke imaju pravo biti upoznate sa stavovima suda o pitanjima koja se odnose na postupak i pravo izjašnjavanja o njima.

6. Načelo strogog formalnog legaliteta - određuje da se u postupku postojanje tražbina i legitimacija stranaka može dokazivati samo kvalificiranim ovršnim ili vjerodostojnim ispravama.

7. Načelo usmenosti i pismenosti - određuje da je postupak u pravilu pismeni postupak, jer sud postupa na temelju podnesaka i drugih pismena, a usmeno saslušanje ne mora biti provedeno na ročištu za prodaju.

8. Načelo javnosti - određuje da o postupku neupitno moraju biti obaviješteni svi sudionici postupka.

9. Načelo zakonskog i diskrecijskog reda - određuje da su osnovni stadiji postupka i redoslijed u provedbi ovršnih radnji striktno određeni.

10. Načelo savjesnog korištenja postupovnih ovlaštenja - određuje da je dužnost stranaka da pred sudom govore istinu i da se savjesno koriste pravima koja im pripadaju u postupku, te dužnost suda da onemogući svaku zlouporabu tih prava.

11. Načelo ekonomičnosti - određuje da sud može, iz posebno opravdanih razloga, dozvoliti ekonomsku eksploataciju stvari (broda) koja je predmet ovrhe. $^{3}$

3 Podaci o osnovnim načelima postupka ovrhe preuzeti na www.nasciturus.com/skriptarnica/doc_ view/304-ovrsno-pravo. Stranica pregledana 15. kolovoza 2019. 


\section{POSTUPOVNE RADNJE PRIJE PRODAJE BRODA}

Podnošenjem prijedloga za ovrhu od strane ovrhovoditelja i njegovim prihvaćenjem od strane nadležnog suda, sud donosi rješenje o ovrsi i započinje postupak ovrhe sa svojim postupovnim (ovršnim) radnjama. Postupovne radnje prije prodaje broda odnose se na donošenje rješenja o ovrsi, zabilježbu ovrhe u upisnik brodova odnosno brodova u gradnji, određivanje privremene mjere zaustavljanja broda, utvrđivanje vrijednosti broda odnosno broda u gradnji, te konačno na prodaju broda odnosno broda u gradnji i nastavljaju ovršnim radnjama nakon izvršene prodaje broda.Te radnje odnose se na isplatu i razdiobu kupovnine te naplatu vjerovnika iz iznosa dobivenog prodajom broda.

\subsection{Pravne nejasnoće prilikom podnošenja prijedloga za ovrhu}

Prijedlog za ovrhu i isprave koje je ovrhovoditelj dužan priložiti utvrđeni su člancima 854. i 855. PZ-a. Podnošenje prijedloga mora biti u skladu s načelom strogog formalnog legaliteta. Veći dio odredbi tih članaka je jasan i nedvosmislen, pa upućuje ovrhovoditelja kako ispravno udovoljiti zakonskoj formi ovršnog prijedloga. Podnošenje ovršne ili vjerodostojne isprave temelj je cijelog postupka, jer bez takve isprave nema ni postupka ovrhe. ${ }^{4}$ Međutim, odredbe koje se odnose na podnošenje nekih drugih podataka ili isprava koje je ovrhovoditelj dužan dodatno priložiti pravno su dvojbene i nedovoljno utvrđene i mogu ovrhovoditelja staviti u nezavidan položaj. Iz odredbi nije jasno hoće li prijedlog za ovrhu biti odbijen ako se ne podnesu traženi podaci. Tu se misli na podnošenje podataka o popisu poznatih založnih ovrhovoditelja, popisa o poznatim privilegijima i isprave kojom se dokazuje vlasništvo ovršenika na brodu. U trenutku podnošenja prijedloga za ovrhu, ovrhovoditelj ne mora znati koliki je broj ovrhovoditelja i pomorskih privilegija koji opterećuju brod, jer za postanak i pravni učinak pomorskih privilegija prema trećim osobama nije potreban upis u upisnik brodova. Ako prijedlog za ovrhu podnese hipotekarni vjerovnik, on bi se mogao naći u situaciji da ne naplati svoju tražbinu, jer da je prije pokretanja postupka znao za broj pomorskih privilegija koji opterećuju brod, a naplaćuju se prije hipoteke, vjerojatno ne bi niti podnio prijedlog za ovrhu. Za njega bi bilo povoljnije da se koristi s druge dvije ovlasti koje mu daju odredbe Pomorskog zakonika - izvansudsku prodaju broda i preuzimanje broda u posjed i iskorištavanje broda do naplate svoje tražbine. ${ }^{5}$ Ovrhovoditelja može dovesti u

4 Čl. 855. st. 1. t. 1 PZ-a. Uz prijedlog ovrhovoditelj treba priložiti ispravu na temelju koje se traži ovrha (ovršna ili vjerodostojna isprava), u izvorniku ili u ovjerovljenom prijepisu. Po odredbama članka 23. St. 1 . i čl. 24. st. 1 . Ovršnog zakona NN 112/12, 25/13, 93/14, 55/16, 73/17 (dalje OZ), ovršne isprave su ovršna sudska odluka i ovršna sudska nagodba. Po odredbama čl. 31. st. 1. i st. 2. OZ-a vjerodostojne isprave su:račun, mjenica, ček s protestom i povratnim računima kad je to potrebno za zasnivanje tražbine, javna isprava, izvadak iz poslovnih knjiga, po zakonu ovjerovljena privatna isprava koja se po posebnim propisima smatra javnom ispravom. Računom se smatra i obračun kamata. Vjerodostojna isprava je podobna za ovrhu ako su u njoj naznačeni vjerovnik i dužnik te predmet, vrsta, opseg i vrijeme ispunjenja novčane tražbine.

5 Arg. iz čl. 219. st. 1. PZ-a. 
nezavidan položaj i dio odredbi članka 855. st. 2. u slučaju da se ovrha pokreće na brodu koji nije upisan na ovršenika već na drugu osobu. U takvom slučaju ovrhovoditelj je dužan podnijeti, osim prijedloga za ovrhu, i ispravu koja je podobna za upis ovršenikova prava. Kakva je to isprava i kako se do nje može doći odredbe PZ-a ne navode, pa je u ovom slučaju velika mogućnost zlouporabe od strane ovršenika. Ovršenik (stvarni vlasnik) koji ekonomski eksploatira brod, želi svojim zlonamjernim raspolaganjem, prepisujući brod drugoj osobi (formalnom vlasniku), onemogućiti ovrhovoditelja da prisilno naplati svoju tražbinu. Kako nema odredbi, pretpostavka je da vjerovnik mora pokrenuti građansku parnicu u kojoj dokazuje da je za njega nastupila šteta zlouporabom stvarnog i fiktivnog vlasnika, te uputiti zahtjev da ove pravne radnje prema njemu ne proizvode pravni učinak. Sudska odluka kojom je vjerovnik (ovrhovoditelj) uspio u parnici dokazati zlouporabu mogla bi biti ta isprava koju treba priložiti prilikom podnošenja prijedloga za ovrhu. Dodatna parnica produžava cjelokupni postupak ovrhe i donosi nepredviđene troškove ovrhovoditelju. Moguća je i pojava slučaja kad ne postoji zlouporaba dužnika (ovršenika) prema vjerovniku. Dužnik provodi pravne radnje protiv druge osobe, u svoje ime i za svoj račun, kako bi zaštitio svoja povrijeđena subjektivna prava, jer je njegov brod ušao bez pravne osnove u imovinu te druge osobe. Pretpostavka je da bi isprava kojom je dužnik uspješno dokazao svoje vlasništvo na brodu bila ta koju je ovrhovoditelj dužan priložiti prilikom podnošenja prijedloga za ovrhu. Međutim, i ova situacija može ovrhovoditelju donijeti nove troškove, jer bez dodatnog istraživanja niti ne može doći do ove isprave. Ovršenik nema pravni interes i zakonsku obvezu da mu dobrovoljno ustupi ispravu koja se neposredno ne odnosi na postupak, jer ne želi pokretanje postupka ovrhe i prodaju svoga broda. Postoji još jedna problematična odredba članka 855 . st. 5. PZ-a u slučaju provedbe ovrhe na zaustavljenom stranom brodu. Rok od tri dana u kojem je ovrhovoditelj dužan priložiti potrebne isprave (prema st. 3. ovoga članka) neprikladan je i prekratak u slučaju pojave posebnih okolnosti ili više sile kad ne može pravno djelovati u zadanome roku. Ako ne postupi u zadanome roku (prema st. 6. ovoga članka), sud će rješenjem obustaviti postupak. Takve okolnosti mogu biti iznenadna bolest ovrhovoditelja, neodgodivi put u inozemstvo ili smrt člana uže obitelji. Ovu odredbu treba nadopuniti na način da je u slučaju pojave posebnih okolnosti ovrhovoditelj dužan neoborivo dokazati sudu razlog pravnog nepostupanja u zadanome roku, ili taj rok od tri dana treba produžiti do nekog razumnog okvira kako bi ovrhovoditelj bio u prilici naplatiti svoju nespornu tražbinu.

\subsection{Dvojbena pitanja djelokruga i načina postupanja ovršnog suda}

Nakon podnošenja prijedloga za ovrhu na temelju ovršne ili vjerodostojne isprave, nadležni sud odlučuje o formalno pravnim uvjetima koji moraju biti zadovoljeni i donosi rješenje o ovrsi. Dio odredbi članaka 844. - 846. PZ-a koje reguliraju sudsko djelovanje u postupku ovrhe na brodu previše su uopćene i neodređene pa stvaraju dodatne nedoumice i troškove ovrhovoditelju. U određenim slučajevima ovrhovoditelj ima ovlast vršiti pravne radnje pred drugim stvarno 
Mr. sc. Dean Vuleta: Pravni status sudionika u kompleksnom postupku ovrhe na brodu radi naplate... Zbornik radova Pravnog fakulteta u Splitu, god. 57, 4/2020, str. 1113-1139

nadležnim sudovima, osim mjesno nadležnim sudom. ${ }^{6}$ Takve su okolnosti kad nije poznata lokacija broda pod ovrhom, a time i nadležan sud za poduzimanje postupovnih radnji od strane ovrhovoditelja. Naime, sud neko vrijeme odlučuje o osnovanosti ovršnog prijedloga prije nego što donese rješenje o ovrsi i privremenu mjeru zaustavljanja broda. U tom vremenu ovršenik gospodarski eksploatira brod koji se zbog svoje mobilnosti kratkotrajno zadržava na jednoj lokaciji (luci). Ovršeniku kao protivniku ovrhe i prodaje svoga broda od kojeg ima ekonomsku korist odgovara odugovlačenje ovršnog postupka, pa nema pravni interes i zakonsku obvezu predočiti ovrhovoditelju potrebne informacije o lokaciji broda. Ako ovrhovoditelj želi doznati plovidbenu rutu broda i destinaciju (lokaciju) njegove sljedeće luke, kako bi znao koji je sud nadležan za poduzimanje postupovnih radnji, mora podnijeti dodatne troškove. Takvi su troškovi, primjerice, angažiranje pomorskog agenta koji će u ime i za račun nalogodavca-ovrhovoditelja provoditi određene radnje. Te radnje uključuju praćenje plovidbene rute ovršenikovog broda, posjet nekoj luci ako postoji opravdana sumnja da je to lokacija njemu interesantnog broda, ili se očekuje uplovljavanje broda u luku, posjet nekoj lučkoj kapetaniji koja posjeduje relevantne podatke o brodu i druge radnje kojima je cilj utvrđivanje destinacije broda, odnosno nadležnog suda pred kojim ovrhovoditelj može pravno postupati. ${ }^{7}$ Brod pod ovrhom i brod u gradnji pod ovrhom nemaju jednaki pravni status. Dok se za brod veže problematika nadležnog suda za provedbu ovrhe, takva problematika ne postoji u slučaju kad se radi o brodu u gradnji. Brod u gradnji uvijek je lociran na jednom mjestu (brodogradilištu), dok se ne završi gradnja i dobije uporabna dozvola, pa je u svakom trenutku poznat mjesno nadležan sud za odlučivanje o prijedlogu za ovrhu i za provedbu ovrhe. Veći dio problematike koja proizlazi iz djelokruga postupanja ovršnog suda zakonodavac bi mogao riješiti malom korekcijom opće odredbe članka 860. t. 1. PZ-a koja određuje da ovršni sud započinje s provedbom ovrhe u trenutku kad donese, odnosno kad primi rješenje o ovrsi. Korekcijom sadašnje zakonske odredbe o početku provedbe ovrhe značajno bi se popravila efikasnost i trajanje postupka. Sud bi trebao započeti s provedbom ovrhe na brodu upisanom u upisnik brodova trenutkom primanja prijedloga za ovrhu, a ne donošenjem ili primanjem rješenja o ovrsi. Ako je potrebno sud bi, pod prijetnjom sankcija, naredio ovršeniku ili službenoj osobi ovršenika da predoči potrebne podatke o brodu. U tom trenutku sud bi trebao odrediti i privremenu mjeru

${ }^{6}$ Mjesnu nadležnost suda utvrđuju čl. 844. st. 1. i čl. 845. st. 1. PZ-a. Za odlučivanje o prijedlogu za ovrhu na brodu, odnosno brodu u gradnji upisanom u upisnik brodova mjesno je nadležan sud na području nadležne lučke kapetanije za upis kako je određeno u skladu s člankom 254.ovoga Zakonika (članak 844. st.1.PZ-a). Za odlučivanje o prijedlogu za ovrhu i za provedbu ovrhe na stranom brodu i na domaćem brodu, odnosno brodu u gradnji koji nije upisan u upisnik brodova, mjesno je nadležan sud na čijem se području nalazi brod, odnosno brod u gradnji u vrijeme podnošenja prijedloga za ovrhu (članak 845. st. 1. PZ-a). Ovlasti ovrhovoditelja za podnošenje isprava stvarno nadležnim sudovima, u posebnim okolnostima, utvrđuju čl. 844. st. 2. i čl. 845. st. 2. PZ-a. Provedbu rješenja o ovrsi iz st. 1. ovoga članka ovrhovoditelj može zatražiti pred svakim stvarno nadležnim sudom na čijem se području zatekne brod u vrijeme kad ovrhu treba provesti (čl. 844. st. 2. PZ-a). Ako se u vrijeme provedbe ovrhe brod iz st. 1. ovoga članka ne nađe na području suda koji je ovrhu odredio, ovrhovoditelj može radi provedbe ovrhe podnijeti rješenje o ovrsi svakom stvarno nadležnom sudu na području kojega se brod nađe s prijedlogom da taj sud provede ovrhu.

7 O poslovima pomorskog agenta članci 674. - 683. PZ-a. 
zaustavljanja broda zabranom napuštanja luke. To je logično rješenje, jer bi sud nadležan za donošenje rješenja o ovrsi bio nadležan i za provedbu tog rješenja. U slučaju donošenja nove odredbe i podnošenja prijedloga za ovrhu na domaćem brodu koji nije upisan u upisnik brodova, ili na stranom brodu, ovrhovoditelj nema dodatnih troškova ako zna gdje se brod nalazi, pa je sud te lokacije broda nadležan za donošenje rješenja o ovrsi i za provedbu ovrhe. Ako ne zna gdje se brod nalazi mora podnijeti troškove nalaženja lokacije (luke) broda kako bi nadležan sud na području te luke donio rješenje o ovrsi i proveo ovrhu. I u ovom slučaju mogao bi se popraviti pravni status ovrhovoditelja donošenjem nove zakonske odredbe po kojoj je ovršenik, ili odgovorna osoba ovršenika (zapovjednik broda), dužna predočiti sudu lokaciju odnosno plovidbenu rutu broda. Tako nema dodatnih troškova koje mora podnijeti ovrhovoditelj. Ako tako ovršenik ne postupi u određenom roku, sud bi mu kao sankciju odredio novčanu kaznu. U sadašnjim odredbama OZ-a i PZ-a postoji uporište za donošenje novčane ili zatvorske kazne u određenim slučajevima. ${ }^{8}$ Ako prijedlog za ovrhu, čijim podnošenjem započinje postupak provedbe ovrhe, bude odbijen od strane suda zbog nepropisane forme, ili iz bilo kojeg drugog pravno opravdanog razloga, ovršenik može pretrpjeti štetu. Zbog dokazivanja nastupa štetnih okolnosti po njega i traženja naknade pretrpljene štete, ovršenik može radi zaštite svojih subjektivnih prava pokrenuti posebnu parnicu.

\subsection{Donošenje i dostava rješenja o ovrsi}

Rješenje o ovrsi sudska je isprava koja predstavlja temelj cjelokupnog postupka ovrhe na brodu. Nakon podnošenja prijedloga za ovrhu od strane ovrhovoditelja, nadležni sud odlučuje o osnovanosti prijedloga te donosi rješenje o ovrsi i pristupa praktičnoj provedbi postupka. Rješenje o ovrsi na brodu regulira PZ člancima 856. - 859. Po čl. 856. st. 1. način dostavljanja rješenja o ovrsi i ostalih pismena određuje se po čl. 8. OZ-a. Novi OZ u 2020. godini donosi novosti koje se dijelom odnose i na dostavu rješenja o ovrsi. Novi OZ uvest će šire korištenje sredstava elektroničke komunikacije i propisanih obrazaca između sudova, javnih bilježnika i stranaka u postupku, čime bi ovršni postupak trebao biti jednostavniji za sve njegove sudionike. Promjene su usmjerene prema većoj zaštiti dostojanstva dužnika u ovršnom postupku. Glavna je promjena njegovo vraćanje pod nadzor suda koji će biti opće i redovito tijelo pa sudska nadležnost postaje pravilo dok javni bilježnici postaju pomoćno tijelo u postupku. Tako se omogućuje da rješenja koja se donesu u ovršnom postupku budu u skladu s pravom Europske unije. Radi boljeg ostvarenja načela zaštite dužnika, po pitanju dostave rješenja o ovrsi, postojećim odredbama novi OZ

8 Odredbe čl. 16. st. 1. - 3. OZ-a utvrđuju visinu novčane kazne fizičkim i pravnim osobama u postupku ovrhe, ako se ne pokore odluci suda. Stavak 4. utvrđuje uvjete kad se ta kazna može zamijeniti kaznom zatvora.

Čl. 994. c st. 1. PZ-a. Novčanom kaznom u iznosu od 2000 do 20.000 kuna kaznit će se pravna osoba, vlasnik odnosno brodar ako ne postupi u skladu sa zabranom, ograničenjem ili drugom naredbom iz članka 75. ovoga Zakonika. Čl. 75 st. 1. PZ-a. U obavljanju službe nadzora i upravljanja pomorskim prometom, za to ovlašteni djelatnik može određenom plovnom objektu ili skupini plovnih objekata izdati određene naredbe. 
dodaje odredbe kojima se podiže sigurnost dostave. Dužnika se obavještava dva puta izravno, s povratnicom, poštom. Tek nakon dva bezuspješna pokušaja dostave, ona ide putem oglasne ploče uz obvezno slanje obavijesti dužniku u poštanski sandučić i osobni korisnički pretinac e-građani. Kad je riječ o pokretninama (ovrha na brodu) i nekretninama, novi zakon predviđa aktivniju ulogu ovrhovoditelja koji će morati nazočiti ovrhama. U slučajevima u kojima se ovrhovoditelj više puta ne odazove pozivu na ovrhu, omogućuje se obustava postupka. Cilj odredbe jest skraćenje ovršnog postupka. ${ }^{9}$ Međutim, u praksi postupka ovrhe na brodu dostava rješenja o ovrsi ovršeniku može izazvati nejasnoće zbog nedosljednosti i neusklađenosti odredbi OZ-a i PZ-a koje reguliraju dostavu. Ako već odredbe čl. 856. st. 1. određuju da se dostava obavlja po odredbama OZ-a o osobnoj dostavi (članak 8), onda dolazi do direktne kolizije odredbi PZ-a i OZ-a. Kako postojeći OZ (odredbama čl. 8. st. 4., 5. i 6.) kvalitetno rješava pitanje dostave osobama koje ne obavljaju upisanu djelatnost, a novi OZ bi dopunama u potpunosti trebao riješiti pitanje dostave, postavlja se pitanje opravdanosti postojanja odredbi st. 3. čl. 856. PZ-a. One utvrđuju dostavu rješenja o ovrsi zapovjedniku broda i postavljanje privremenog zastupnika, ako je boravište ovršenika nepoznato, ili ako se ovršenik nalazi u inozemstvu. Odredbama o dostavi OZ-a, odredbe st. 3. čl. 856. PZ-a postaju nepotrebne pa ih treba brisati.

\subsubsection{Nedoumice kod zabilježbe rješenja o ovrsi}

Članak 857. st. 1. - 5. PZ-a određuje učinak zabilježbe rješenja o ovrsi. Te su odredbe jasne i nedvosmislene. Međutim, odredbe st. 6. i st. 7. ovoga članka treba dodatno utvrditi kako bi se izbjegle nejasnoće i eventualni prijepori između dva ili više ovrhovoditelja ako sudjeluju u postupku ovrhe. U praksi je moguća i pravno dopuštena promjena vlasnika nakon zabilježbe rješenja o ovrsi, ali nije dopušten upis promjene prava vlasništva. Profitabilnost ekonomskog iskorištavanja broda može biti razlog raspoložbi nakon zabilježbe kroz ulazak u pravni odnos kupoprodaje broda između prethodnog vlasnika (ovršenika) i novog vlasnika koji preuzima pravni status ovršenika. Pravni interes u ovom slučaju mogu imati sve zainteresirane strane u ovršnom postupku. Prethodni vlasnik prodaje brod novom vlasniku po tržišnoj cijeni ili drugoj odgovarajućoj cijeni koja vjerojatno ne bi bila postignuta na javnoj dražbi i rješava se statusa ovršenika. Novi vlasnik ugovorio je jedan ili više plovidbenih pothvata, iako svjestan svog pravnog statusa ovršenika i rizika koji donosi ovrha, ali računa da će iznosom dobivenim od ekonomske eksploatacije broda podmiriti sudske troškove postupka, sve tražbine vjerovnika i iznos potreban za kupnju broda. U odredbama čl. 866. PZ-a postoji uporište za ovakvu raspoložbu prema kojoj sud može dopustiti da brod u tijeku ovrhe poduzme jedno ili više putovanja ako za to postoje opravdani razlozi. Sud ce sigurno odobriti jedno ili više putovanja ako novi vlasnik zadovolji uvjete iz čl. 866. i dokaže sudu pravnu osnovu u vidu ugovora s naručiteljem prijevoza. Vjerovnici nemaju razloga protiviti

9 https://w.w.w.dashofer.hr/sto-donosi-novi-ovrsni-zakon-novosti-u-provedbi, https://tockanai.hr> Biznis>Financije. Stranice pregledane 20. kolovoza 2019. 
se ovoj raspoložbi jer je njihov pravni interes brzo naplatiti svoje tražbine prije dugotrajnog i neizvjesnog ovršnog postupka. U slučaju postojanja više od jednog ovrhovoditelja, u postupku mogu nastati problematične situacije i prijepori među njima zbog nedovoljne utvrđenosti odredbi st. 6. i 7. čl. 857. PZ-a. ${ }^{10} \mathrm{Kad}$ u postupku sudjeluju dva ili više ovrhovoditelja, za prvenstveni red prava na naplatu odlučujući je trenutak kad je tijelu koje vodi upisnik brodova podnesen zaključak suda kojim se nalaže zabilježba rješenja o ovrsi. Sud zaključak kojim se nalaže zabilježba šalje po zakonskim odredbama OZ-a o dostavi pismena i moguća je situacija da taj zaključak suda kojim se nalaže zabilježba rješenja o ovrsi ovrhovoditelja koji je prije stekao pravo na naplatu, greškom u dostavi ili iz nepoznatog razloga, stigne kasnije tijelu koje vodi upisnik brodova nego zaključak suda koji se odnosi na ovrhovoditelja koji je kasnije stekao pravo na naplatu. U tom slučaju ovrhovoditelju koji je kasnije stekao pravo na naplatu pripada prvenstvo u naplati zato što je zaključak suda o zabilježbi ovrhe stigao prije tijelu koje vodi upisnik brodova nego zaključak suda koji se odnosi na ovrhovoditelja koji ima stvarno prvenstvo u naplati. Ovi slučajevi bi mogli izazvati nepotrebne prijepore. Mogu biti nesporni kad bi za prvenstveni red prava na naplatu koji pripada ovrhovoditelju bio odlučujući trenutak kad je tijelu koje vodi upisnik brodova upućen zaključak suda kojim se nalaže zabilježba rješenja o ovrsi, a ne trenutak kad je tijelu koji vodi upisnik brodova podnesen taj zaključak. Slično rješenje trebalo bi primijeniti kad brod nije upisan u upisnik brodova. Ako je sud nadležan za donošenje rješenja o ovrsi, red prvenstva trebao bi se određivati prema trenutku kad je tom sudu upućen prijedlog za ovrhu, a ne, kako je utvrđeno sadašnjim odredbama - prema trenutku kad je taj sud odredio obavljanje pljenidbenog popisa.

\subsection{Pravni status sudionika kod određivanja privremenih mjera na brodu}

Nakon što je u upisnik brodova izvršena zabilježba rješenja o ovrsi, odnosno izvršen pljenidbeni popis broda, sud kreće u provedbu ovrhe određivanjem privremenih mjera na brodu i u tu svrhu postupa po odredbama čl. 860. - 862. PZ-a uz primjenu odredaba čl. 865. st. 1., čl. 866. i čl. 960. PZ-a.

Ova veoma bitna faza postupka određivanja i provođenja privremenih mjera na brodu najmanje je utvrđena odredbama PZ-a i primjer je nedorečenosti koja izaziva veliku pravnu nesigurnost sudionika postupka (neposrednih i dijela posrednih - zapovjednika i članova posade broda). Posebna problematika vezana je za određivanje mjere čuvanja broda, postavljanje čuvara broda te troškove čuvanja i održavanja broda. Dolazi i do kolizije odredbi čl. 865. st. 1. i čl. 960. st. 1. po

10 Čl. 857. st. 6. Za prvenstveni red prava na namirenje koji pripada ovrhovoditelju odlučujući je trenutak kad je tijelu koje vodi upisnik brodova podnesen zaključak suda kojim se nalaže zabilježba rješenja o ovrsi u smislu st. 1. ovoga članka. Stavak 7. Ako predmet ovrhe nije upisan u upisnik brodova, red prvenstva određuje se prema trenutku kad je zamolnica za provođenje popisa upućena sudu nadležnom za provedbu ovrhe, odnosno ako je taj sud nadležan za donošenje rješenja o ovrsi - prema trenutku kad je taj sud odredio obavljanje pljenidbenog popisa. 
pitanju održavanja broda. ${ }^{11}$ Logično bi bilo da ovršenik, koji je u praksi najčešće i brodar, kao vlasnik broda do donošenja rješenja o dosudi broda, čuva i održava svoj brod. Međutim, zakonodavac u ovom slučaju daje samo formalno pravno rješenje bez logičnosti. Prije prisilnog zaustavljanja broda, za vrijeme plovidbenog pothvata i drugih načina gospodarskog iskorištavanja broda, zapovjednik i posada broda, kao zaposlenici brodara (ovršenika), dužni su čuvati i održavati brod kao dio svojih radnih dužnosti. Nakon određivanja privremene mjere zaustavljanja, brodu je zabranjeno isplovljavanje iz luke na čijem je području sud koji provodi ovrhu. Po čl. 951. PZ-a, nakon zaustavljanja, ovršeniku se zabranjuje otuđenje broda i bilo koja druga raspoložba koja bi mogla štetiti ovrhovoditelju. Sud po svojoj subjektivnoj odluci može, ali i ne mora, odrediti čuvanje broda. Nije utvrđeno kakva bi to trebala biti opasnost po brod da se treba donijeti ta mjera. Posada po dužnosti čuva i održava brod, bez obzira na to je li brod u plovidbi ili na vezu u luci. Ta subjektivna ocjena suda, bez normiranja granica i situacija u kojima sud odlučuje na takav način, stavlja neposredne sudionike u vrlo težak položaj, a neki od posrednih sudionika mogu ostati bez posla i u stanju ugrožene egzistencije. Ukoliko sud odredi mjeru čuvanja broda za brodara (ovršenika), mogu nastati neplanirani problemi i prijepori koji proizlaze iz njegova pravnog odnosa s kapetanom i ostalim članovima posade broda (prava iz radnog odnosa). U ovoj izvanrednoj situaciji, kad je brod prisilno zaustavljen u gospodarskoj eksploataciji, problematično je reguliranje viška utvrđenog zakonskog radnog vremena zbog povećanja opsega posla koji zasigurno čeka zapovjednika i članove posade određene da ostanu na brodu kao čuvari. Prema odredbi čl. 61. st. 1. Zakona o radu NN 93/14, 127/17 puno radno vrijeme ne može biti dulje od 40 sati tjedno. Način i regulacija prava i obveza iz radnog odnosa članova posade koji su se morali iskrcati s broda i tako ostati bez posla, mogu stvoriti dodatne probleme i prijepore ovršeniku kao poslodavcu. Određivanje privremene mjere čuvanja broda donosi i ovrhovoditelju nove neplanirane troškove, jer on mora predujmiti troškove čuvanja broda, a visina tih troškova i način predujmljivanja nisu utvrđeni. Takve problematike ne bi niti bilo da ta mjera nije određena. Zbog toga nema nikakvog pravnog razloga za donošenje mjere čuvanja broda i određivanje čuvara broda. Pogotovo nema razloga da se dio posade, ili kapetan sa cijelom posadom, iskrcaju s broda ako nisu određeni za čuvare. Tome ide u prilog i odredba čl. 866. st. 1. PZ-a da sud može na prijedlog zainteresirane osobe, ako za to postoje posebno opravdani razlozi, dopustiti da brod u tijeku ovrhe poduzme jedno ili više putovanja. Sud u pravilu dopušta putovanje ako se tome ne protive stranke i poznati vjerovnici koji na brodu imaju neki stvarnopravni teret. Takva je raspoložba u interesu svih strana, jer bi ovršenik mogao doći do novčanih sredstava da svojevoljno podmiri sve tražbine i dotadašnje troškove postupka. U slučaju da ovršenik ne ostvari dovoljno novčanih sredstava da podmiri sve svoje obveze iz ovršnog postupka, prema čl. 910. st. 1. t. 4. PZ-a, prihodi od putovanja koje je obavljeno za postupka prodaje ulaze u diobnu masu. Za putovanja su potrebni kapetan i članovi posade broda pa nema razloga za

11 Arg. iz čl. 865. st. 1., troškove čuvanja i održavanja broda prethodno snosi ovrhovoditelj. Arg. iz čl. 960. st. 1., troškove održavanja broda i uzdržavanja posade za vrijeme privremene mjere zaustavljanja snosi vlasnik broda ili brodar. 
njihovo iskrcavanje po odluci suda. Cjelokupna problematika može biti lako rješiva pod određenim uvjetima, odnosno korekcijama i nadopunama postojećih odredbi koje reguliraju privremene mjere na brodu. Korekcije bi značile da treba brisati sve odredbe PZ-a koje utvrđuju ili se posredno odnose na mjere čuvanja i održavanja broda te postavljanje čuvara broda. ${ }^{12}$ Nadopune znače da se odredbama koje reguliraju zaustavljanje broda (bez odredbi o čuvanju i održavanju broda) trebaju pridodati nove odredbe, ili uvrstiti postojeće odredbe PZ-a i OZ-a o sankcijama u ovršnom postupku. ${ }^{13}$ Novčane i eventualno zatvorska kazna trebaju se odrediti ovršeniku ili odgovornoj osobi ovršenika - zapovjedniku broda, u slučaju nepostupanja po naredbi suda ili nalogu ovlaštene sudske osobe. Moguće je da neposredno prije određivanja mjere zaustavljanja broda, ili čak nakon određivanja takve mjere i sudske zabrane isplovljavanja, brod isplovi prema nepoznatoj destinaciji. Sud bi tada trebao zaprijetiti sankcijama ovršeniku i zapovjedniku broda ako ne postupe po nalogu suda i brod ne vrate u luku provedbe ovrhe. Ukoliko tako ne postupe, sud im određuje primjerenu sankciju. Isto tako, sud bi odredio sankciju ovršeniku ili zapovjedniku broda, ukoliko na zaustavljenom brodu čine nedozvoljene radnje na štetu ovrhovoditelja (zabrane, otuđenja ili bilo kojih raspoložbi na brodu). U ovoj situaciji korigiranih i nadopunjenih odredbi o privremenim mjerama, odredbe o čuvanju i održavanju broda postaju nepotrebne i pravno irelevantne.

\subsection{Problematika utvrđivanja vrijednosti broda}

Nakon što je po rješenju o ovrsi brod zaustavljen, sud pristupa sljedećoj fazi u provedbi ovrhe te zaključkom određuje način utvrđivanja vrijednosti broda i postupa po odredbama čl. 867. - 869. PZ-a. Nepostojanje knjižnog režima za pomorske privilegije utječe i na postupak utvrđivanja vrijednosti broda i problematiku koja prati tu fazu postupka ovrhe. Uz knjižni režim bi svi vjerovnici, a ne samo oni poznati sudu, dobili rješenje o ovrsi i bili obavješteni o ročištu za utvrđivanje vrijednosti broda. Na tom ročištu utvrdila bi se stvarna vrijednost broda pa ne bi postojala potreba da se ona ponovno utvrđuje na ročištu za prodaju eventualnom pojavom novih vjerovnika. Ovrhovoditelj može predložiti sudu da pokrene postupak utvrđivanja vrijednosti i prije pravomoćnosti rješenja o ovrsi ako za to ima određeni ekonomski i pravni interes. S obzirom na varijabilnost kretanja cijena na tržištu brodova u kratkom periodu, ovrhovoditelj ili više njih mogu imati različite ekonomske i pravne interese, pa se različito i ponašaju u postupku ovrhe. Jedan ovrhovoditelj koji je pokrenuo ovrhu, a kome je poznato kretanje cijena na tržištu brodova gdje se očekuje rast tih cijena (vrijednosti broda), nakon pravomoćnosti rješenja o ovrsi, želi da utvrđena vrijednost bude manja, pa predlaže sudu utvrđivanje vrijednosti broda prije pravomoćnosti rješenja o ovrsi dok je cijena broda na tržištu niža. Niža cijena znači i manju utvrđenu vrijednost broda. Njegov je ekonomski

12 To su odredbe ili samo dio odredbi čl. 860. Točka 2., cijeli čl. 861., čl. 862. st. 1., čl. 863. st. 2. i st. 3., čl. 864. st. 2., čl. 865. st. 1., čl. 951. st. 1. i čl. 960. st. 3. PZ-a.

13 Sankcije u ovršnom postupku reguliraju čl. 16. st. 1. - 4. OZ-a i čl. 994. c. st. 1. PZ-a. 
i pravni interes u tome da će se brod uz manju vrijednost (cijenu) lakše prodati na ročištu za prodaju. On smatra da će tako efikasno naplatiti svoju tražbinu, a pravni status ostalih vjerovnika ga ne interesira. Ovrhovoditelj može imati i interes u otkupu broda na javnoj dražbi uz manju cijenu, pogotovo ako se na dražbi pojavi kao jedini ponuditelj. Kako u postupku ovrhe mogu sudjelovati dva i više ovrhovoditelja, ovrhovoditelj s najboljim prvenstvenim redom u naplati tražbine može predložiti sudu utvrđivanje vrijednosti broda prije pravomoćnosti rješenja o ovrsi da bi brže i efikasnije naplatio svoju tražbinu. Položaj ostalih ovrhovoditelja ga ne interesira. Postupak mogu pokrenuti i ovrhovoditelji sa suprotnim pravnim interesom. Oni su svjesni svog slabijeg prvenstvenog reda u naplati tražbina, pa žele veću tržišnu cijenu broda kako bi imali šansu naplatiti svoje tražbine poslije vjerovnika s boljim prvenstvenim redom. Oni predlažu sudu utvrđivanje vrijednosti prije pravomoćnosti rješenja o ovrsi, jer se nakon pravomoćnosti rješenja očekuje manja cijena broda koja će biti uzrok i manje utvrđene vrijednosti. Isto tako, ovršenik ima pravni interes veće utvrđene vrijednosti broda, jer je time veća šansa da se okoristi iznosom preostalim nakon naplate svih vjerovnika i troškova postupka. Nakon pravomoćnosti rješenja o ovrsi, a prema odredbama čl. 868. st. 1. PZ-a o ročištu za utvrđivanje vrijednosti broda i popisa pripadaka sud obavještava stranke. Međutim prema čl. 880. st. 6. vjerovnici, koji nisu bili obaviješteni o ročištu za utvrđivanje, jer sud nema podataka o njihovim tražbinama, mogu svoje privilegirane tražbine prijaviti i nakon ročišta za utvrđivanje vrijednosti, najkasnije na ročištu za prodaju broda. Oni su za ročište doznali privatnim putem. To znači da tek na ročištu za prodaju može biti poznata stvarna utvrđena vrijednost broda u odnosu na onu koja je utvrđena prije ročišta za prodaju. Veća opterećenost tražbinama znači manju vrijednost broda i pad ranije utvrđene vrijednosti broda. Zakonodavac je pokušao smanjiti problematiku utvrđivanja vrijednosti dajući strankama određene ovlasti. ${ }^{14}$ Ova ovlast je neadekvatna jer stranka može doznati o izmjenama vrijednosti broda prijavom tražbina vjerovnika tek na ročištu za prodaju, a ne osam dana prije ročišta. Time se dolazi do problematičnosti naplate tražbina svih vjerovnika, pa će sud ocijeniti je li prodaja svrsishodna s obzirom na mogućnost naplate tražbina vjerovnika i eventualno obustaviti ovrhu zbog nemogućnosti naplate.

\subsection{Uvjeti i način prodaje broda}

Uvjeti i način prodaje broda određeni su člancima 870. - 878. PZ-a. Nakon provedbe postupka za utvrđivanje vrijednosti broda, sud donosi zaključak o prodaji broda kojim se utvrđuje vrijednost i određuju uvjeti i način prodaje te vrijeme $\mathrm{i}$ mjesto ako se prodaja obavlja dražbom. Na usmenoj javnoj dražbi mogu sudjelovati samo osobe koje polože jamčevinu, a koja u pravilu iznosi deseti dio utvrđene vrijednosti broda. Na prvom ročištu za dražbu brod se ne smije prodati ispod jedne

14 Čl. 867. st. 7. PZ-a. Sud će na prijedlog stranke koji mora biti podnesen najkasnije osam dana prije ročišta za prodaju, na ročištu za prodaju zaključkom ponovno utvrditi vrijednost broda ako stranka učini vjerojatnim da se ta vrijednost izmijenila za više od jedne petine od dana prethodnog utvrđivanja vrijednosti do dana podnošenja prijedloga. 
polovice utvrđene vrijednosti. Ako se brod ne proda na prvom ročištu, sud će odrediti drugo ročište na kojemu se brod može prodati i ispod polovice utvrđene vrijednosti, ali ne ispod jedne trećine te vrijednosti. Od prvog do drugog ročišta za dražbu mora proteći najmanje petnaest dana. Stranke i vjerovnici koji se naplaćuju u postupku mogu se sporazumjeti da se brod može prodati dražbom i za cijenu nižu od jedne polovice, odnosno jedne trećine utvrđene vrijednosti broda. U slučaju neuspješne prve i druge dražbene prodaje, jer nije postignuta najniža prihvatljiva ponuda, sud će odrediti novo ročište za prodaju ako ga predloži ovrhovoditelj (čl. 896.). Osim prodaje usmenom javnom dražbom, brod se može prodati u određenom roku neposrednom pogodbom, najkasnije do prodaje broda na javnoj dražbi, ako se tako dogovore stranke, založni vjerovnici i nositelji osobnih služnosti koje prestaju prodajom broda. Međutim, brod se može prodati i ako treća osoba, najkasnije osam dana prije ročišta za prodaju, izjavi da je spremna preuzeti brod za cijenu koja je veća za najmanje jednu četvrtinu od utvrđene vrijednosti broda.

\subsubsection{Nadponuda treće osobe i neodređeni pravni status nadponuditelja}

Zakonodavac je predvidio i specifičnu nadponudu, odnosno preuzimanje broda od strane treće osobe prije ročišta za prodaju. Odredbe čl. 904. st. 1. točka 1. PZ-a određuju da će sud obustaviti postupak ovrhe ako treća osoba najkasnije osam dana prije ročišta za prodaju, dajući primjereno osiguranje, izjavi da je spremna preuzeti (otkupiti) brod koji je predmet ovrhe za cijenu koja utvrđenu vrijednost broda prelazi najmanje za jednu četvrtinu i ako izjavi da će snositi sve troškove koje bi inače trebao snositi ovršenik. Ova mogućnost nadponude predstavlja pogodnost sudionicima postupka. Kako je teško za očekivati da će se na dražbi postići cijena koja nadmašuje utvrđenu vrijednost broda najmanje za jednu četvrtinu, ovrhovoditelj i ostali vjerovnici ovom nadponudom dolaze u šansu da brže naplate svoju tražbinu bez daljnjeg nastavka postupka, a ovršenik da se okoristi ostatkom iznosa nakon podmirenja svih obveza. Postavlja se pitanje zašto bi neka treća osoba preuzela brod i platila sve troškove koje je dužan snositi ovršenik, pogotovo za cijenu koja utvrđenu vrijednost broda prelazi najmanje za jednu četvrtinu. Nadponuditelj je mogao pričekati kratko vrijeme do ročišta za prodaju gdje bi bila veća šansa za preuzimanje broda po mnogo povoljnijim uvjetima. Međutim, postoje stanoviti rizici u pogledu cijene koje donosi dražbena prodaja. Kako je brod stvar velike vrijednosti, eventualni sudionici dražbe (ponuditelji) ne mogu biti sigurni koja će cijena biti postignuta na prvom ročištu za dražbu. ${ }^{15}$ Ona može biti mnogo veća od utvrđene vrijednosti, pa nadponuditelj ne želi preuzeti rizik koji donosi javna dražba. Bez obzira na nepovoljne uvjete za njega, on može imati pravni interes da ugovorenim plovidbenim pothvatima pokrije sve svoje troškove. Nepostojanje odredbi kojima bi se potpuno regulirao pravni status nadponuditelja uzrok su derogiranja važnosti nadponude. Nejasno je zašto zakonodavac nije odredbama

15 Čl. 876. st. 1. i st. 2. PZ-a. Na prvom ročištu za dražbu brod se ne može prodati ispod $1 / 2$ utvrđene vrijednosti. Ako se ne proda na prvom ročištu, sud će odrediti drugo ročište na kojem se brod može prodati ispod $1 / 2$, ali ne ispod1/3 utvrđene vrijednosti. 
dao ovlast trećoj osobi da svoju nadponudu predloži i na ročištu za prodaju, a ne najkasnije osam dana prije ročišta, pogotovo ako na javnoj dražbi nedostaje sudionika dražbe (ponuditelja). Problematična pitanja bez odgovora jesu kriteriji za preuzimanje broda po cijeni koja utvrđenu vrijednost prelazi za najmanje jednu četvrtinu, te iznos primjerenog osiguranja koji mora predložiti. Kriterij po kojemu je zakonodavac predvidio baš jednu četvrtinu, odnosno najmanje za jednu četvrtinu, nije poznat. Jedan nadponuditelj može ponuditi iznos koji prelazi jednu četvrtinu utvrđene vrijednosti i položi primjereno osiguranje, a nakon njega drugi nadponuditelj (nadponuditelji) dade još povoljniju nadponudu koja prelazi jednu trećinu ili čak jednu polovinu utvrđene vrijednosti. Postavlja se pitanje koja su prava drugog (drugih) nadponuditelja i međusobni odnos s prvim nadponuditeljem. Iz odredbi nije jasno razjašnjeno, pa bi se dalo zaključiti da kad treća osoba predloži nadponudu koja utvrđenu vrijednost prelazi za jednu četvrtinu, makar to bio zanemarujući iznos iznad jedne četvrtine, postupak nadponuđivanja završava. Ova neodređenost djeluje negativno na pravni status zainteresiranih sudionika. Cilj je pravnog instituta nadponude da se što većim ponuđenim iznosom nadponuditelja sudionici ovršnog postupka nađu u boljem pravnom statusu. Da bi se taj cilj ostvario, potrebno je novim odredbama bolje utvrditi pravni status nadponuditelja te dozvoliti i druge nadponude i na samom ročištu za prodaju. Drugo problematično pitanje jest davanje primjerenog osiguranja od strane nadponuditelja po čl. 905. Po stavku 2. ovoga članka određeno je da predlagatelj nadponude treba predložiti primjereno osiguranje u određenom roku, a ako to ne učini, sud će poslužbenoj dužnosti nastaviti postupak koji je odgođen dok nadponuditelj ne izvrši sve svoje obveze. Kako predlagatelj može sam sebi odrediti primjereno osiguranje, koliki je to iznos, po kojim se odredbama i kriterijima određuje nije poznato. U nekom slučaju ovršnog postupka moglo bi se desiti da nadležni sud prihvati prijedlog od strane predlagatelja i odredi manju svotu kao primjereno osiguranje, a drugi nadležni sud u sličnom ovršnom postupku ne prihvati osiguranje, jer smatra da predloženi iznos nije primjeren. Kako nema normativnog kriterija po kojemu sud određuje primjereno osiguranje, u ovom drugom slučaju nastavlja se neizvjestan i mukotrpan postupak ovrhe. Sud je jedino tijelo koje može odrediti primjereno osiguranje, ali samo po odredbama koje bi trebao utvrditi PZ. Ako bi se nadponuda mogla tretirati kao postupak koji prethodi javnoj dražbi, onda bi primjereni iznos osiguranja koji mora položiti nadponuditelj, ili više njih, bio postotak od utvrđene vrijednosti broda koji moraju položiti sudionici javne dražbe, a iznosi deseti dio utvrđene vrijednosti broda.

\subsection{Pravni status privilegiranog vjerovnika na ročištu za prodaju broda}

Prodaja broda usmenom javnom dražbom na ročištu za prodaju i način oglašavanja prodaje PZ utvrđuje odredbama čl. 879. - 895. Sud ne mora imati saznanja o svim privilegijima koji opterećuju brod, jer ne postoje podaci u upisniku brodova, a privilegirani vjerovnici za čije tražbine ne postoji evidencija mogu biti u situaciji da ne dobiju rješenje o ovrsi. Osim toga, treba znati da privilegirane 
tražbine prestaju ovršnom prodajom broda. Ako nisu dobili rješenje o ovrsi i oglas o prodaji, ne moraju niti znati za pokrenuti postupak, osim ako privatnim istraživanjem ne doznaju za pokrenuti postupak, pa mogu svoju tražbinu prijaviti najkasnije na ročištu za prodaju. Nejasnoće izaziva odredba da založni (privilegirani) vjerovnik, čija prava nisu upisana u upisnik brodova, može prijaviti svoju tražbinu najkasnije na ročištu za prodaju. Pri tome nije decidirano određeno do kojeg trenutka na ročištu za prodaju može prijaviti svoju tražbinu. Brod se prodaje na ročištu za prodaju usmenom javnom dražbom. Dakle, ročište za prodaju traje dokle traje dražba, odnosno do trenutka kad se prestalo davati ponude. Potpunim tumačenjem odredbe dade se zaključiti da privilegirani vjerovnik može prijaviti svoju tražbinu do kraja dražbe. Međutim, to nije bila intencija zakonodavca već prijava tražbine na ročištu za prodaju, ali prije početka usmene javne dražbe. Prijavom tražbine na ročištu utvrđena vrijednost broda koja je određena prije ročišta pada. Tako je na ročištu potrebno ponovno utvrđivanje vrijednosti broda kako bi ponuditelji početkom usmene javne dražbe znali koja je najniža prihvatljiva ponuda. U zaključku o prodaji sud će posebno istaknuti mogućnost da se vrijednost broda konačno utvrdi na ročištu za prodaju. Dakle, jasna je intencija zakonodavca da početkom usmene javne dražbe privilegirani vjerovnik ne može više prijaviti svoju tražbinu na prvom ročištu za dražbu. Zakonodavac je propustio bitno popraviti status privilegiranog vjerovnika da je decidiranim odredbama (trenutno nepostojećim) utvrdio moguću situaciju koja se može dogoditi u praksi. Naime, moguće je da na prvom ročištu za dražbu brod nije prodan, jer nije ponuđena najniža prihvatljiva ponuda. Privilegirani vjerovnik koji nije znao za ročište za prodaju privatnim istraživanjem, u roku od petnaest dana koji mora proteći od prvog do drugog ročišta za dražbu, dozna za datum održavanja drugog ročišta za dražbu. Po trenutno važećim odredbama, on nema nikakve ovlasti poduzimanja postupovnih radnji. Zakonodavac je odredbama trebao predvidjeti ovakvu situaciju i privilegiranom vjerovniku dati ovlast da na drugom ročištu za dražbu može prijaviti svoju tražbinu. Sud bi u takvom slučaju odredio ponovno utvrđivanje vrijednosti broda i nastavio dražbu po postojećim odredbama. Nerazjašnjen je pravni status privilegiranog vjerovnika u slučaju da niti na drugom ročištu za dražbu nije postignuta najniža prihvatljiva ponuda (jedna trećina utvrđene vrijednosti broda), pa je sud odredio novo ročište za prodaju broda. Između prvog ročišta za prodaju i novog ročišta mora proteći najmanje trideset dana. Nema valjanog pravnog razloga da zakonodavac i u ovom slučaju odredbama ne da ovlast poduzimanja postupovnih radnji privilegiranom vjerovniku, ako naknadno dozna za novo ročište za prodaju. Strogim tumačenjem trenutno važećih odredbi on takvih ovlasti nema.

\subsection{Raspoložba kupca te ovršenika i kupca kao razlog za ponovnu prodaju}

Ako kupac u određenom roku ne položi kupovninu, sud će rješenjem prodaju proglasiti nevažećom i odrediti ponovnu prodaju. Ponovnu prodaju, razloge za 
određivanje i pravne posljedice takve prodaje utvrđuje čl. 902. st. 1. - 7. PZ-a. Razlozi zbog kojih kupac nije položio kupovninu mogu biti višestruki. To mogu biti novonastale okolnosti koje su se pojavile u postupku ovrhe ili zlonamjerna raspoložba ovršenika i kupca. Opravdani razlog bio bi kad bi kupac u roku u kojem mora isplatiti kupovninu upao u financijske probleme pa nije ni u mogućnosti da je isplati, ali mora podnijeti pravne posljedice svoje raspoložbe (prema čl. 902. st. 2. PZ-a). Drugi slučaj može biti kad je kupac prije pravomoćnosti rješenja o dosudi, u roku kad je trebao isplatiti kupovninu, doznao za okolnosti koje mu ne idu u prilog (npr. preinaka rješenja o ovrsi) te zbog toga nije isplatio kupovninu u određenom roku u zaključku o prodaji, jer smatra da su mu manji troškovi oduzetog osiguranja nego troškovi koje bi morao podnijeti u eventualnom parničenju s ovršenikom. Prema čl. 895. st. 1. PZ-a, ovršenik, na temelju novih okolnosti, dobiva ovlast pobijanja rješenja o dosudi žalbom jer ono nije više u skladu sa sadržajem sudskih spisa na kojima se temelji. Isto tako, u praksi bi se mogli pojaviti slučajevi da ovršenik svojim zlonamjernim raspoložbama, u dogovoru s fiktivnim kupcem koji uopće nema namjeru isplatiti kupovninu, odugovlači ovršni postupak radi svojih osobnih razloga. Krajnji cilj ovršenika je obustavljanje ovršnog postupka kako ne bi došlo do prodaje njegovog broda, makar taj cilj bio postignut i zlouporabom. Motivi za takvo njegovo postupanje mogu biti višestruki, pa zbog toga želi što više produžiti ovršni postupak odnosno njegovo trajanje. Jedan od motiva ovršenika može biti financijsko iscrpljivanje ovrhovoditelja kao kazna za pokretanje postupka ovrhe. Isto tako, ovršenik ne može biti siguran hoće li na javnoj dražbi biti stavljena cijena dovoljna za preuzimanje broda, odnosno hoće li se na ročištu za prodaju pojaviti barem jedan ponuditelj. Zbog toga ovršenik s fiktivnim kupcem dogovara stavljanje najbolje ponude na dražbi, bez obzira na broj ponuditelja koji sudjeluju na dražbi i na visinu njihovih ponuda. Oboje znaju da kupovnina neće biti isplaćena u propisanome roku, pa će sud biti prisiljen proglasiti prodaju nevažećom i odrediti ponovnu prodaju. Jamčevina (osiguranje) fiktivnog kupca koristi se za troškove ponovne prodaje, ali ovršenik smatra da je jamčevina koju mora položiti fiktivni kupac zanemariv iznos u odnosu na korist koju ovršenik očekuje zlouporabom. ${ }^{16}$ Motiv ovršenika može biti i očekivani rast cijene broda na tržištu u kraćem budućem periodu do ponovne prodaje. Na ponovnoj prodaji utvrđena vrijednost broda bi bila veća, a time i veća šansa ovršenika da se okoristi ostatkom iznosa preostalim nakon naplate troškova postupka i tražbina vjerovnika. Ovakve raspoložbe ovršenika i fiktivnog kupca bile bi uzrok neopravdano produljenog postupka ovrhe, a pričinile bi štetu svim vjerovnicima. Ako se ovakve zlouporabe dokažu u postupku, zakonodavac bi ih mogao spriječiti samo kad bi dopunio postojeće odredbe čl. 902. i 903. PZ-a i utvrdio primjerenu sankciju za ove raspoložbe.

16 Čl. 874. st. 2. i st. 3. PZ-a određuje da jamčevina koju moraju položiti ponuditelji na dražbi iznosi u pravilu deseti dio utvrđene vrijednosti broda. Jamčevina najboljeg ponuditelja služi kao zalog za sve obveze koje nastanu protiv njega iz postupka prodaje. 


\section{POSTUPOVNE RADNJE NAKON IZVRŠENE PRODAJE BRODA}

To su radnje koje se provode uz sudsko djelovanje prema zakonskim odredbama PZ-a i prema potrebi OZ-a, a slijede nakon izvršene prodaje broda, s konačnim ciljem naplate svih troškova postupka i tražbina vjerovnika. Odnose se na isplatu kupovnine od strane kupca, određivanje ročišta za razdiobu kupovnine s popratnim radnjama vezanima za ročište, te naplatu tražbina. Za razliku od postupovnih radnji prije prodaje broda koje su striktno utvrđene odredbama, u ovom dijelu postupka ovrhe mogu se pojaviti situacije koje nije moguće unaprijed predvidjeti a za koje je potrebno dodatno sudsko djelovanje. Tu se prvenstveno misli na eventualne prijepore na ročištu za razdiobu kupovnine, a u nekim slučajevima i na protuovrhu.

\subsection{Isplata kupovnine od strane kupca}

Kupac je dužan položiti kupovninu sudu ili javnom bilježniku u roku koji je određen u zaključku o prodaji. Prava i obveze kupca utvrđeni su odredbama čl. 877. i 878. PZ-a. Na zahtjev kupca koji je u roku položio kupovninu, te udovoljio posebnim uvjetima prodaje broda, ako su bili određeni, sud može odrediti predaju broda kupcu i prije pravomoćnosti rješenja o dosudi, ako to opravdavaju ekonomski razlozi. ${ }^{17}$ Ova odredba u potpunosti štiti prava kupca. Prema odredbama čl. 890. st. 1. ostali ponuditelji mogu podnijeti prigovor protiv dosude najboljem ponuditelju (kupcu) odmah nakon završetka dražbe na ročištu za prodaju. Ako nisu imali razloga za prigovor na ročištu, vjerojatno ga neće imati ni kasnije, jer su se pomirili s činjenicom da je brod prodan najboljem ponuditelju (kupcu), premda imaju pravo istaknuti prigovor protiv dosude u žalbi protiv rješenja o dosudi. Interes kupca je što brža eksploatacija broda koja bi donosila ekonomsku korist. Iako su cijene na tržištu brodova varijabilne, dakle mogu porasti naviše u kratkom periodu, kupac u pravilu kupuje brod radi ekonomske eksploatacije, rjeđe radi preprodaje, jer računa da će budućim plovidbenim pothvatima ostvariti dovoljnu ekonomsku korist koja će pokriti sve troškove. U tom slučaju sud će predaju broda kupcu prije pravomoćnosti rješenja o dosudi uvjetovati polaganjem primjerenog osiguranja koje će se moći koristiti ako u slučaju ukidanja rješenja o dosudi kupac ne vrati brod u stanju u kakvom mu je bio predan. Iznos i uvjete tog osiguranja odredit će sud prema okolnostima slučaja.

\subsection{Ročište za raspravu o razdiobi kupovnine i pravni status vjerovnika na ročištu}

Prema čl. 908., koji određuje način razdiobe kupovnine, kad kupac izvrši svoju obvezu prema ovršnom sudu, položi kupovninu u roku određenom u zaključku o prodaji, a rješenje o dosudi postane pravomoćno, sud će odrediti dan održavanja

17 Arg. iz čl. 878. st. 3. PZ-a. 
ročišta na kojem će se raspravljati o načinu razdiobe kupovnine. Pozivi za sudjelovanje na ročištu osobama s pravom prvokupa i kupcu pravno su irelevantni jer su oni svoje pravne interese mogli ostvariti ili su ih ostvarili prije ročišta za razdiobu kupovnine. Ovlaštenici prava prvokupa mogu se pozivati na svoje pravo do postupka prodaje, pa na ročištu za razdiobu više nemaju svoju ovlast, osim ako nisu kupili brod. Kupac je svoj pravni interes ostvario stjecanjem prava vlasništva na brodu, nakon što mu je ispunjenjem svih obveza i poslije pravomoćnosti rješenja o dosudi brod predan, pa nema razloga sudjelovati na ročištu za razdiobu kupovnine. Koliko je kompleksan, neutvrđen i težak pravni status založnih (privilegiranih) vjerovnika čija prava nisu upisana u upisnik brodova pokazuje nam i ova faza postupka ovrhe na brodu razdioba kupovnine. Ukoliko ovi vjerovnici dođu na ročište za razdiobu kupovnine pozivajući se na čl. 880. st. 6. PZ-a, s jasnim pismenim dokazom o postojanju svojih tražbina kojima inače nema traga u upisniku brodova i ovršnim spisima, neodređenost ovog stavka dolazi do punog izražaja. U prvom dijelu tog stavka navodi se da oni mogu svoje tražbine prijaviti najkasnije na ročištu za prodaju kako bi se uvele u ovršne spise. Tu je jasno izražena intencija zakonodavca, jer nakon završetka ročišta za prodaju oni više nemaju ovlasti prijaviti svoje tražbine. Međutim, drugi dio odredbe da će se njihova prava u postupku uzeti u obzir samo ako proizlaze iz ovršnih spisa otvara mogućnost dvostrukog tumačenja ovoga stavka. ${ }^{18}$ Kako postupak ovrhe traje do pravomoćnosti rješenja o naplati tražbina, doslovnim i logičnim tumačenjem riječi postupak, privilegirani vjerovnici mogli bi zaključiti da i kasnije mogu prijaviti svoje tražbine, najkasnije na ročištu za razdiobu kupovnine. Pravno je nedopustivo da založni (privilegirani) vjerovnici koji nisu znali ili nisu mogli znati za postupak ovrhe, bez svoje krivnje, zbog nepostojanja knjižnog režima za takve tražbine, nemaju ovlast prijaviti svoje tražbine u bilo kojoj fazi postupka ovrhe kako bi bile uvedene u ovršne spise, naravno, do trenutka pravomoćnosti rješenja o naplati tražbina. Time bi mogli ravnopravno sudjelovati u postupku ovrhe, najkasnije na ročištu za razdiobu kupovnine gdje bi mogli drugim osobama osporavati postojanje njihovih tražbina, njihovu visinu i red po kojem se te tražbine naplaćuju. ${ }^{19}$ Članak 909. PZ-a navodi da će se na ročištu za razdiobu raspravljati o tražbinama koje bi u razdiobi kupovnine trebalo uvažiti, a to su zasigurno tražbine o kojima vjerovnik posjeduje pismeni dokaz, makar se pojavio tek na ročištu za razdiobu kupovnine. Pojavljivanju novih vjerovnika i njihovim tražbinama mogao bi se usprotiviti ovršenik koji u ovoj situaciji ima manju šansu da se okoristi ostatkom iznosa preostalim nakon naplate troškova postupka i tražbina vjerovnika. Mogli bi se usprotiviti i ostali založni vjerovnici, pogotovo ako se pojavom novih zahtjeva za naplatom smanjuje njihova šansa za naplatom, s obzirom na prvenstveni red $\mathrm{u}$ naplati. Trenutne odredbe PZ-a i moguće opisane situacije koje se mogu pojaviti u sudskoj praksi, bez decidiranih i potpuno utvrđenih odredbi, zasigurno bi dovele do parnica s novim i nepredviđenim troškovima. Te bi se parnice mogle odvijati

18 Čl. 880. st. 6. PZ-a. Poziv založnim vjerovnicima čija prava nisu upisana u upisnik brodova da najkasnije na ročištu za prodaju prijave svoje tražbine, s upozorenjem da će se njihova prava u postupku uzeti u obzir samo ako proizlaze iz ovršnih spisa.

19 Arg. iz čl. 908. st. 3. i čl. 909. st. 1. PZ-a. 
između ovršenika i novog vjerovnika, jer ovršenik može tvrditi da je ova tražbina prijavljena prekasno pa nema pravne osnove za naplatu. Isto tako, parnicu bi mogli pokrenuti i ostali vjerovnici protiv novog vjerovnika, jer bi nova prijavljena tražbina mogla poremetiti njihov prvenstveni red naplate, pa i samu naplatu. Hipotekarne vjerovnike ne prati takva vrsta problematike, jer se oni namiruju iz diobne mase i kada nisu prijavili svoje tražbine.

\subsubsection{Naplata tražbina i mogući prijepori na ročištu za razdiobu kupovnine}

Vjerovnici se naplaćuju iz diobne mase prema utvrđenom redu prvenstva. ${ }^{20}$ Naplata tražbina regulirana je odredbama čl. 911. - 923. PZ-a. Članak 912. utvrđuje red prvenstva u naplati tražbina. Prema ovome članku, troškovi nastali u tijeku postupka prodaje broda naplaćuju se prije razdiobe kupovnine, pa i prije bilo koje tražbine vjerovnika. Vjerovnici se podmiruju iz diobne mase prema ovom redu prvenstva:

1) vjerovnici čije su tražbine osigurane zakonskim založnim pravom s osnova članaka 171. i $840 \mathrm{u},{ }^{21}$

2) vjerovnici čije su tražbine osigurane pomorskim privilegijem,

3) vjerovnici koji imaju po ovom Zakoniku pravo zadržaja, ${ }^{22}$

20 Čl. 910. st. 1. PZ-a. Diobnu masu čine: 1)kupovnina, 2) jamčevina što ju je položio kupac koji je zakasnio s plaćanjem, 3) plodovi i prihodi dobiveni od broda koji je predmet ovrhe koje je kupac dužan vratiti, 4) prihodi od putovanja koje je obavljeno za postupka prodaje, 5) svote iz st. 2. i 3. ovoga članka. St. 2. Kupovnina što se odnosi na brod koji je predmet ovrhe, uzgrednosti broda koji je predmet ovrhe, vozarina, odnosno prevoznina čine posebne diobne mase ovisno o tome na koju se od tih vrijednosti odnose privilegiji ili hipoteke ovrhovoditelja koji su predložili ovrhu. St. 3. Vozarina, prevoznina i svote koje se odnose na uzgrednosti broda koje su plaćene do zaključenja ročišta za raspravu o razdiobi kupovnine podijelit će se rješenjem kojim se razdjeljuje kupovnina postignuta prodajom broda koji je predmet ovrhe.

21 To je skupina vjerovnika koju uvodi najnovija novela PZ-a NN 17/19. Prema čl. 171. PZ-a, ako se u obavljanju inspekcijskog nadzora utvrde nedostaci broda u pogledu njegove sposobnosti za plovidbu, naredit će se zapovjedniku broda da u određenom roku otkloni utvrđene nedostatke. Ako se utvrđeni nedostaci ne otklone u određenom roku, zabranit će se brodu daljnja plovidba dok se nedostaci ne otklone i oduzet će mu se isprava o sposobnosti za plovidbu. Osim toga, ako brod predstavlja ili može predstavljati opasnost za luke, plovne putove ili plovidbu, nadležna lučka kapetanija će rješenjem narediti vlasniku broda da u primjerenom roku poduzme mjere za otklanjanje nedostataka. Ako vlasnik broda ne postupi tako, kapetanija će rješenjem narediti tijelu koje upravlja lukom, da ga na rizik i trošak vlasnika ukloni. Uklanjanje broda može uključivati i prodaju broda na javnoj dražbi. U pogledu tražbine koja se tiče naknade troškova uklanjanja broda, Republika Hrvatska, odnosno ovlašteno tijelo koje je uklonilo brod ima založno pravo na brodu koji je predmet uklanjanja te ga može i zadržati do podmirenja tražbine. Čl. 840.u odnosi se na potonulu stvar, odnosno podrtinu uz podrednu primjenu čl. 840.n st. 4., 6. i 7. te čl. 840.s st. 4., 5. i 6. PZ-a. Kad nadležna lučka kapetanija utvrdi da potonula stvar, odnosno podrtina predstavlja opasnost, naredit će rješenjem vlasniku da u primjerenom roku ukloni potonulu stvar, odnosno podrtinu. Ako vlasnik ne postupi po rješenju, lučka kapetanija će rješenjem narediti ovlaštenom tijelu da na rizik i trošak vlasnika odmah ukloni potonulu stvar ili podrtinu, uključujući i njezinu prodaju na javnoj dražbi. Vjerovnici (Republika Hrvatska odnosno ovlašteno tijelo koje je uklonilo potonulu stvar ili podrtinu) ovlašteni su naplatiti svoje tražbine iz prodajne cijene potonule stvari ili podrtine ostvarene prodajom na javnoj dražbi, ili sudskom prodajom odgovarajućom primjenom odredbi glave druge dijela devetog ovoga Zakonika.

22 Prema čl. 437. PZ-a brodograditelji i brodopopravljači koji drže u posjedu brod u gradnji ili na popravku imaju pravo zadržati brod, dok im ne budu isplaćene tražbine u vezi s ugovorom o gradnji ili popravku broda. 
Mr. sc. Dean Vuleta: Pravni status sudionika u kompleksnom postupku ovrhe na brodu radi naplate... Zbornik radova Pravnog fakulteta u Splitu, god. 57, 4/2020, str. 1113-1139

4) vjerovnici čije su tražbine osigurane hipotekom na brodu,

5) ostali vjerovnici.

Određeni hipotekarni vjerovnici i njihove tražbine mogu se naći u problematičnoj situaciji zbog nejasnoće odredbi članka 922. PZ-a. Radi se o vjerovnicima čije su hipotekarne tražbine po svojem redu prvenstva u naplati pokrivene diobnom masom, ali se ne zna identitet sadašnjeg vjerovnika, odnosno tko je sadašnji ovlaštenik te hipotekarne tražbine, ili mu se ne zna boravište. Utvrđeno je da će sud u ovom slučaju položiti svotu koja se odnosi na ovu tražbinu, u banku kao štedni ulog, a u rješenju o razdiobi kupovnine odrediti kome će ta svota pripasti ako je vjerovnik ne podigne u roku od tri godine od dana kada je bila položena u banku. Svaki vjerovnik kojemu bi ta svota ili njezin dio imala pripasti može tražiti da mu se isplati svota koja odgovara njegovoj tražbini. Ovršenik može tražiti isplatu ako ne postoje takvi vjerovnici. Ako je sud u potpunosti primijenio odredbe članka 8. OZ-a o dostavi pismena u ovršnom postupku ne bi smjelo biti nedoumica tko je sadašnji vjerovnik hipotekarne tražbine. Za upis u upisnik brodova i pravne učinke hipoteke potrebna je pisana forma u kojoj je jasno utvrđen identitet vjerovnika i dužnika, predmet nad kojim se proteže hipoteka, iznos tražbine i ostali relevantni podaci. Postavlja se pitanje kako bi se mogla zasnovati hipoteka bez ovakvih podataka, osim pod pretpostavkom da je hipotekarni vjerovnik iz njemu poznatih razloga dao krive podatke za koje se kasnije utvrdi da su pogrešni, pa nije poznato tko je sadašnji titular hipotekarne tražbine. Upitan je i rok od tri godine kako utvrđuje st. 2. ovoga članka. Taj rok je neopravdano dug, jer ako se u nekom primjerenom kraćem roku ne doznaju relevantni podaci o vjerovniku, vjerojatno i neće. Vjerovnik koji bi tražio isplatu dijela ili cjelokupnog iznosa ove svote položene u banku bio bi neopravdano dugo uskraćen za traženi iznos. Ovo se odnosi i na ovršenika koji može tražiti taj iznos u slučaju kad nema ovakvih vjerovnika. Nakon održanog ročišta za razdiobu kupovnine, prema čl. 925. st. 1. i 2. PZ-a, s obzirom na stanje u upisniku brodova, ovršnim spisima i postignutim rezultatima na ročištu, sud donosi rješenje kojim odlučuje o naplati ovrhovoditelja i ostalih vjerovnika koji imaju pravo na naplatu svojih tražbina. U rješenju sud odlučuje o prigovorima koje su istaknuli vjerovnici i ostali sudionici postupka, a odnose se na koje pravno pitanje. Međutim, na ročištu za razdiobu su mogući i prijepori između zainteresiranih strana. Među samim vjerovnicima može doći do osporavanja tražbina, njihove visine i prvenstvenog reda u naplati. Tražbine hipotekarnih vjerovnika teško je osporiti, jer je njihovo pravo nastalo upisom u upisnik brodova i prije pokretanja postupka ovrhe, a proizvodi pravne učinke prema svima od trenutka tog upisa. Eventualno bi drugi hipotekarni vjerovnici mogli osporiti prvenstveni red naplate, s obzirom na vrijeme kad je prijedlog za upis stigao lučkoj kapetaniji. Moguća je i prijeporna situacija kad se na ročištu pojavi više privilegiranih vjerovnika čije su tražbine s naslova nagrade za spašavanje broda. Oni međusobno mogu osporavati prvenstveni red u naplati, jer je sporno vrijeme nastanka tražbine. Tražbine s naslova nagrade za spašavanje broda međusobno imaju red prvenstva suprotan redoslijedu vremena nastanka tražbine koje osiguravaju. Smatra se da su takve tražbine nastale onoga dana kad je dovršena svaka pojedina radnja spašavanja. Realna je i prijeporna situacija kad 
jedan ili više privilegiranih vjerovnika osporavaju privilegiranu tražbinu drugom privilegiranom vjerovniku, jer se njegova tražbina temelji na vjerodostojnoj ispravi sumnjivog porijekla. Zbog velike mobilnosti broda, međunarodnog karaktera pomorskog gospodarstva i isprepletenih pravnih odnosa među domaćim i inozemnim sudionicima pomorskog prometa, može doći do provedbe ovrhe na stranom brodu. Moguće su situacije kad treba odlučiti da li vjerovnik ima ili nema privilegij, jer ga ostali vjerovnici osporavaju na ročištu za razdiobu kupovnine. Ako sud utvrdi da tražbina postoji, mora odlučiti koji je međusobni odnos s drugim tražbinama, odnosno kakvo je rangiranje i prvenstveni red naplate među tražbinama. Tu se postavlja pitanje po kojem će mjerodavnom pravu sud riješiti ovu situaciju. Problem se može dodatno zakomplicirati kad je brod opterećen s više tražbina koje mogu biti privilegirane. Ako je brod opterećen samo jednim privilegijem koji je priznat po pravu državne pripadnosti broda, te hipotekom (mortgage) ili drugim tražbinama, prvenstveni red naplate nije sporan. Privilegiji se naplaćuju prije svih drugih tražbina vjerovnika prema svakom pravu državne pripadnosti broda. Međutim, u pomorskom prometu brod je najčešće opterećen $s$ više privilegija. Prema odredbama čl. 969. st. 1. t. 2. PZ-a, status stvarnih prava, time i pomorskih privilegija, ocjenjuje se prema pravu državne pripadnosti broda. Ova odredba nije potpuno određena. Ne može se sa sigurnošću tvrditi da se priznavanje privilegija i prvenstveni red naplate ocjenjuje po pravu državne pripadnosti broda. Tumačenjem odredbi čl. 914. PZ-a koje određuju da se u postupku ovrhe pred hrvatskim sudom, za ocjenjivanje prvenstvenog reda naplate privilegiranih vjerovnika, primjenjuju odredbe PZ-a, moglo bi se zaključiti da je za priznavanje privilegija mjerodavno pravo državne pripadnosti broda, a za prvenstveni red u naplati odredbe PZ-a. Kako nema decidiranog utvrđenja, vjerojatna intencija zakonodavca jest da se priznavanje privilegija i prvenstveni red naplate odvija po pravu državne pripadnosti broda. Ako su rezultati postignuti na ročištu za razdiobu kupovnine doveli do prijepora među sudionicima postupka po pitanju statusa tražbina, odnosno osporavanja tražbina, sud će donošenje rješenja o naplati osobe čija je tražbina osporena odgoditi do završetka parnice. Kad rješenje o razdiobi kupovnine postane pravomoćno, sud će isplatiti svote koje se imaju predati pojedinim vjerovnicima, osim onih u pogledu kojih teče parnica ili upravni postupak. Ako se rješenje o razdiobi kupovnine ne može sprovesti zato što je u tijeku kakva parnica ili upravni postupak, svota koja se odnosi na taj dio rješenja o razdiobi kupovnine položit će se u banku kao štedni ulog do pravomoćnosti odluke o razdiobi. ${ }^{23}$

\subsection{Protuovrha}

Nakon što je ovrha na brodu već provedena, postavlja se pitanje što učiniti kada nastupe izvanredne okolnosti zbog kojih je ovrha protiv ovršenika neosnovano provedena, odnosno koji instrumenti pravne zaštite stoje ovršeniku na raspolaganju u tom slučaju. PZ u svojim odredbama o ovrsi na brodu radi naplate novčane

23 Arg. iz čl. 927. PZ-a. 
tražbine ne regulira ovakvu situaciju, ali odredbama čl. 841. st. 5. navedeno je da će se na ovrhu na brodu radi naplate novčane tražbine na odgovarajući i osobit način primijeniti odredbe OZ-a o ovrsi na nekretnini radi naplate novčane tražbine. OZ svojim odredbama čl. 62. - 64. regulira institut protuovrhe kao način pravne zaštite ovršenika, pa se posrednim tumačenjem čl. 841. st. 5. PZ-a dade zaključiti da će se u ovoj situaciji nakon provedene ovrhe na brodu primijeniti odredbe čl. 62. - 64 . OZ-a. Odredbe ovih članaka utvrđuju bitne elemente ovoga instituta i situaciju kada nastupaju razlozi za protuovrhu. Nakon što je ovrha već provedena, ovršenik može u istom ovršnom postupku zatražiti od suda da naloži ovrhovoditelju da mu vrati ono što je ovrhom dobio. Razlozi koji bi potaknuli ovršenika da zaštiti svoja povrijeđena subjektivna prava jesu: 1. da je ovršna isprava pravomoćno ukinuta, preinačena, poništena, stavljena izvan snage ili je na drugi način utvrđeno da je bez učinka; 2. da je tijekom ovrhe namirio ovrhovoditeljevu novčanu tražbinu izvan ovrhe tako da je ovrhovoditelj dvostruko namiren; 3. da je rješenje o ovrsi pravomoćno ukinuto i prijedlog za ovrhu odbačen ili odbijen, odnosno da je rješenje o ovrsi pravomoćno preinačeno; 4. da je ovrha koja je provedena na određenom predmetu ovrhe (brodu) pravomoćno proglašena nedopuštenom. Ako je u ovim slučajevima nastupila šteta za ovršenika, on može tražiti i ostvariti naknadu te štete u posebnoj parnici. Ovršenik može podnijeti prijedlog za protuovrhu u roku od tri mjeseca od dana kad je saznao za razlog pokretanja protuovrhe, a najkasnije u roku od jedne godine od dana provedbe ovrhe.

\section{OVRHA NA BRODU PO ODREDBAMA NEKIH INOZEMNIH PRAVNIH SUSTAVA}

Države kontinentalnog (europskog) pravnog sustava svojim odredbama kojima se reguliraju pravni odnosi u pomorskom prometu nude uobičajena rješenja. Ipak, neke od tih država svojim odredbama koje reguliraju provedbu ovrhe na brodu odudaraju od uobičajenih, tako i od odredbi našeg PZ-a, pa ih je potrebno dodatno analizirati. Tu se prvenstveno misli na ovršnu prodaju broda u Grčkoj, Portugalu i Italiji.Važno je napomenuti da su i neke specifične odredbe kineskog pomorskog zakonodavstva nesvojstvene drugim pravnim sustavima. Sve su ove odredbe putokaz našem zakonodavcu u eventualnoj nadopuni odredaba PZ-a.

U Grčkoj se ovršna prodaja brodova odvija putem javnih aukcija. Grčki zakon ne poznaje koncept sudske prodaje broda. Postupak ovršne prodaje broda regulira grčki Zakon o parničnom postupku. Prema tom zakonu aukcijski postupci u Grčkoj uglavnom se odvijaju bez sudjelovanja suda. Glavna tijela koja sudjeluju u dražbenom postupku su sudski ovršitelj i javni bilježnik koje je Ministarstvo pravosuđa ovlastilo za provođenje elektroničkih javnih dražbi. Najnovijom novelom zakona od 21. veljače 2018. javne dražbe provode se isključivo elektroničkim putem preko interneta (e-aukcijama) pod nadzorom javnog bilježnika. Svrha je ovog postupka ubrzanje i poboljšanje učinkovitosti ovršnog postupka. Dakle, potencijalni ponuditelji nisu obvezni osobno prisustvovati javnoj dražbi, jer se 
javna dražba provodi isključivo internetskom procedurom. Da bi sudjelovali na dražbi, potencijalni ponuditelji moraju se registrirati na elektroničkoj platformi dva dana prije javne dražbe i položiti jamčevinu u iznosu od $30 \%$ od početne (prve) ponude. Početna ponuda iznosi dvije trećine utvrđene vrijednosti broda. Na ročištu za dražbu ponuditelji daju svoje ponude, svaka viša od prethodne, sve dok brod ne bude dodijeljen najboljem ponuditelju do zaključnog roka dražbe. Ako se na javnoj dražbi ne ponudi nijedna ponuda, ovrhovoditelj može zatražiti da mu se brod preda u posjed radi ekonomske eksploatacije do naplate njegove tražbine. Ako se takav zahtjev ne podnese, određuje se novi datum dražbe. ${ }^{24}$

Ovršna prodaja broda u Portugalu u osnovi je regulirana po Zakonu o parničnom postupku (ZKP) u glavi III - ovršni postupak čl. 886. - 911. Odvija se na nekoliko različitih načina: 1) prodaja putem zatvorenih ponuda (zapečaćenih kuverti);2) putem privatnih pregovora; 3 ) putem dražbe koju organizira i provodi uredno licencirana aukcijska ustanova; 4) elektroničkom dražbom. Najčešći je način sudske prodaje broda putem zatvorenih ponuda. Sud najavljuje prodaju i poziva zainteresirane da pošalju svoje ponude u zapečaćenim kuvertama na adresu suda. Minimalna ponuda mora iznositi $70 \%$ utvrđene vrijednosti broda. Zapečaćene kuverte otvaraju se na posebnom ročištu za prodaju na kojemu mogu sudjelovati ovrhovoditelj, ovršenik, ostali vjerovnici i ponuditelji. Kad se otvore kuverte, sud organizira aukciju među ponuditeljima s najvišim ponudama. Ako prodaja po zapečaćenim kuvertama ne uspije, sud će odobriti prodaju putem privatnih pregovora samo u posebnim slučajevima. Ako ovrhovoditelj predloži otkupnu cijenu i kupca, a to prihvaćaju ovršenik i ostali vjerovnici, ili ako sud smatra da je prodaja hitna zbog propadanja broda odnosno visokih lučkih troškova. Ovakva prodaja odvija se pregovorom koji se vodi između nadležnog suda, odnosno ovlaštenog sudskog tijela, i određene fizičke ili pravne osobe. Ako prodaja putem zatvorenih ponuda ne uspije, niti prodaja putem privatnih pregovora, a u međuvremenu se vrijednost broda toliko smanji da nema relevantnog interesa na tržištu, sud ce odobriti prodaju dražbom. S takvom prodajom broda koju organizira i provodi uredno licencirana aukcijska ustanova moraju se složiti svi zainteresirani sudionici postupka. Najnovijom reformom iz 2008. dana je ovlast sudu da po svojoj subjektivnoj ocjeni odredi elektroničku dražbu, ako smatra da je to najoptimalnije rješenje s obzirom na situaciju. S ovom opcijom se moraju složiti ovrhovoditelj, ovršenik i svi registrirani vjerovnici. Osim metoda ovršne prodaje broda, predviđen je i institut - adjudicacao. Taj pravni institut omogućava ovrhovoditelju ili bilo kojem drugom registriranom vjerovniku kojemu je sud priznao i rangirao njihovo založno pravo na brodu, da licitiraju svojim ponudama u odnosu na brod izložen sudskoj prodaji. Dakle, imaju ovlasti kao ponuditelji sa zapečaćenim kuvertama. ${ }^{25}$

Talijanski Plovidbeni zakonik (Codice della navigazione) regulira postupak ovrhe na brodu čl. 643. - 686. Odredbe Plovidbenog zakonika uglavnom sadrže

24 Podaci o ovršnoj prodaji broda u Grčkoj preuzeti preko internetske tražilice - Procedure for Sale of Vessels Before Maritime Courts. Stranica pregledana 2. listopada 2019.

25 Podaci o ovršnoj prodaji broda u Portugalu preuzeti preko internetske tražilice - portuguese judicial sale of ships, pdf Maritime Law- Area de Docentes. Stranica pregledana 2. listopada 2019. 
uobičajena rješenja Europskog prava. Ipak, Zakonik čl. 661. i 662. koji se odnose na dražbenu prodaju broda nudi neka specifična i kvalitetna rješenja kojima se štite prava svih sudionika postupka. ${ }^{26}$ Sud određuje ročište za prodaju na kojem je utvrđena vrijednost broda najniža prihvatljiva ponuda. Ako se brod ne proda na tom ročištu, odnosno ako nema ponuda, sud će odrediti nova ročišta za dražbu spuštajući cijenu od najmanje $20 \%$ od utvrđene vrijednosti broda u odnosu na prethodno ročište. Ako se cijena spusti na $40 \%$ od utvrđene vrijednosti, a brod se do tada ne proda, sud će saslušati stranke i odrediti da se brod može prodati i izvansudskom prodajom. Posebno su za sve sudionike postupka ovrhe pogodne odredbe čl. 662. koje predviđaju institut nadponude. Naime, najkasnije deset dana nakon dražbene prodaje broda eventualni ponuditelji mogu predati sudu ponude koje su za najmanje $1 / 6$ veće od cijene postignute na dražbi. Ponuditelj mora platiti osiguranje u iznosu $20 \%$ od postignute cijene na dražbi.

Kineski Pomorski postupovni zakon regulira dražbenu prodaju broda čl. 30. $43 .{ }^{27}$ Sadrži odredbe uobičajene za kontinentalni europski pravni sustav, osim čl. 41. čije odredbe, mada nepotpune i nejasno utvrđene, predstavljaju novitet u odnosu na druge međunarodne zakonodavne pomorske akte. Odredbe tog članka određuju da je prodaja ništetna te će se održati novo ročište za prodaju, ili nova prodaja, ako postoji opravdana sumnja o zlonamjernom postupanju ponuditelja. Tu bi prvenstveno moglo biti uključeno neplaćanje kupovnine sa svrhom da se odugovlačenjem postupka spriječi naplata tražbina ovrhovoditelja i ostalih vjerovnika. Posrednim tumačenjem odredbe dade se zaključiti da su one usmjerene na sve zainteresirane sudionike dražbe, jer ovršenik ima najveći pravni interes za ovakvu zlouporabu, mada se u odredbi spominju samo ponuditelji. Ovršenikov krajnji cilj jest obustava ovrhe, kroz odugovlačenje postupka kako bi sačuvao svoj brod od prisilne prodaje, pa može zlorabiti svoje ovlasti u dogovoru s potencijalnim ponuditeljem. Posebno su zanimljive predviđene sankcije za zlouporabe u postupku prodaje broda. Sankcije su predviđene za ponuditelje zbog njihovog nezakonitog postupanja ili zlonamjernog sporazuma radi sprečavanja održavanja dražbe ili naplate vjerovnika. Ponuditelji koji zlouporabe svoje ovlasti i sudjeluju u zlonamjernom sporazumu odgovaraju za troškove i dužni su nadoknaditi svaki gubitak nastao kao plod njihovih nezakonitih raspoložbi. Pomorski sud može odrediti takvim ponuditeljima novčanu kaznu u visini od deset do trideset posto od najviše ponude na dražbi. Ove odredbe predstavljaju jedinstveno rješenje međunarodnog pomorskog pravnog sustava u slučaju ovršne prodaje broda. Ipak, odredbe nisu jasno utvrđene i precizirane, jer nije jasno kakav bi to mogao biti nezakonit i zlonamjeran sporazum postignut među ponuditeljima. Ne spominju se niti eventualne zlouporabe ostalih sudionika dražbe, te ovlašteno sudsko tijelo koje bi, uz regulirani način postupanja i dokazima, prisililo sud da sankcijama kazni te osobe.

26 Podaci o ovršnoj prodaji broda u Italiji preuzeti preko internetske tražilice - Codice della navigazione-Indice_Fog.it. Stranica pregledana 2. listopada 2019.

27 Podaci o kineskom zakonu preuzeti preko internetske tražilice - Special Maritime Procedure Law of the people's Republic of China. Stranica pregledana 2. listopada 2019. 


\section{ZAKLJUČAK}

Osnovni razlog kompleksnog, dugotrajnog i neefikasnog postupka ovrhe na brodu jesu neadekvatne odredbe PZ-a., pa ih treba dopuniti. Prvi je i osnovni korak usklađivanje odredbi čl. 209. st. 1. i čl. 214. st. 1. i st. 2. ovoga članka. Nabrajaju se stvarna prava na brodu (i privilegiji kao jedno od tih prava) i određuje da se stvarna prava na brodu mogu steći, prenijeti, ograničiti i ukinuti jedino upisom u odgovarajući upisnik. Istovremeno, navodi se da za postanak pomorskog privilegija i pravne učinke koji iz tog prava slijede prema trećim osobama nije potreban upis u upisnik brodova. Potrebno je donijeti odredbu o obveznom knjižnom režimu za pomorske privilegije kako bi se olakšao tijek i smanjila problematika cijelog postupka ovrhe, jer najveći dio kompleksnosti i problematičnosti postupka ovisi o saznanju broja privilegija koji opterećuju brod prije prisilne prodaje. Korekcijom odredbe čl. 860. t. 1. po kojem bi provedba ovrhe počela trenutkom podnošenja prijedloga za ovrhu, a ne donošenjem odnosno primitkom rješenja o ovrsi, riješila bi se problematika nadležnog suda te značajno smanjili troškovi, jer bi gotovo u pravilu isti sud bio nadležan za donošenje rješenja o ovrsi i provedbu ovrhe. Odredbama dodatno treba utvrditi da je ovršenik ili njegova službena osoba, ako je potrebno, pod prijetnjom sankcija, dužna predočiti potrebne podatke o brodu (plovidbenu rutu i luku gdje se brod nalazi). Kod zabilježbe rješenja o ovrsi potrebno je nadopuniti odredbe čl. 857. st. 6. i st. 7. PZ-a u slučaju da ovrhu pokrenu dva ili više ovrhovoditelja. Za prvenstveni red prava na naplatu isključivo treba biti odlučujući trenutak kad je određeno pismeno upućeno nadležnom tijelu kako bi se izbjegli nepotrebni prijepori između ovrhovoditelja. Problematika određivanja privremenih mjera na brodu odnosi se isključivo na odredbu čl.860.t.2. po kojoj sud, nakon donošenja privremene mjere zaustavljanja broda iz t. 1. ovoga članka, eventualno može donijeti odluku (po potrebi) o čuvanju i postavljanju čuvara broda. Sve odredbe čl. 860. - 864. koje se neposredno i posredno odnose na mjeru čuvanja i održavanja broda te postavljanja čuvara broda, koji su neutvrđenog pravnog statusa, treba brisati. Te odredbe su nepotrebne i pravno irelevantne, a mogući izvor dugotrajnih prijepora između ovršenika i članova posade broda. Ovršenik je vlasnik broda do okončanja ovrhe, pa čuva i održava svoj brod koji je predmet ovrhe. Kod određivanja privremene mjere zaustavljanja broda iz čl. 860 . t. 1. odredbe treba nadopuniti uvođenjem eventualnih sankcija koje bi sud izrekao ovršeniku, ili odgovornoj osobi ovršenika, ako brod napusti luku nakon određivanja mjere zaustavljanja broda. Prvi dio odredbe čl. 865. st. 1. stavlja ovrhovoditelja kao krucijalnog faktora ovrhe u izuzetno težak i nedefiniran pravni status. Naime, ovrhovoditelj je prethodno obvezan snositi troškove provedbe ovrhe, a sud mu može, ali i ne mora, odrediti polaganje predujma troškova provedbe ovrhe u roku koji određuje sud po subjektivnoj ocjeni. Ako tako ne postupi sud će rješenjem obustaviti ovrhu i spriječiti ovrhovoditelja da naplati svoju nespornu tražbinu. Sve ovo je pravno neprihvatljivo. Ovaj članak treba promijeniti na način da je ovrhovoditelj unaprijed upoznat sa svojim obvezama prilikom pokretanja ovrhe i striktnim rokovima u kojima je dužan postupati. 
Čl. 904. st. 1. t. 1. predviđa specifičnu nadponudu treće osobe - nadponuditelja. Ova mogućnost vrlo je loše utvrđena odredbama, a za takvo stanje nema pravno valjanog razloga. Sadašnja odredba po kojoj nadponuditelj može dati izjavu sudu da želi preuzeti brod, po cijeni koja utvrđenu vrijednost broda prelazi najmanje za $1 \frac{1}{4}$ te vrijednosti uz plaćanje svih troškova, najkasnije osam dana prije ročišta za prodaju je neadekvatna. Potrebno je dodatno utvrditi odredbama da ovrhovoditelj može i na ročištu za prodaju dati svoju izjavu. Isto tako, treba omogućiti i sudjelovanje više nadponuditelja na javnoj dražbi koji bi mogli licitirati svojim nadponudama. Pravni status privilegiranog vjerovnika temelj je postupka ovrhe pa ga je potrebno dodatno regulirati. Postojećim odredbama, do donošenja novih odredbi o uspostavi obveznog knjižnog režima za pomorske privilegije, treba dati ovlast takvom vjerovniku da može prijaviti svoju tražbinu i u kasnijim fazama postupka ovrhe, najkasnije na ročištu za razdiobu kupovnine.

\section{THE LEGAL STATUS OF PARTICIPANTS IN THE COMPLEX FORECLOSURE ON BOARD FOR THE COLLECTION OF MONETARY CLAIMS}

Specific, complex and problematic situations that may arise in a foreclosure procedure to collect a cash claim require a more thorough analysis of all problematic issues. Such situations are a reflection of insufficiently defined provisions that is nonexistent provisions that the legislature has failed to determine, and regulate this procedure for collecting claims. The intention of this paper is to present a unified and systematic account of such issues throughout all stages of the procedure. This can also be compounded by the complex interrelationships between the direct participants involved in the cause and effect of the proceeding, as well as the indirect participants who have a legal interest, and may and may not be affected by the consequences of the proceeding. It should be emphasized that legal doubts are systematically raised about the status of direct and indirect participants in the procedure, as well as the issues of procedural actions of the whole procedure, and not just the enforcement phase on board. Each stage of the proceedings is burdened with more or less problems, without exception, from the submission of a writ of foreclosure to the payment of creditors. Likewise, there may be cases of malicious mischief with the ultimate goal of suspending foreclosure and preventing the sale of the foreclosed ship.The legislature has failed to qualitatively determine this matter, so the solutions of some foreign legal systems, related to the enforcement procedure on board, can serve as a guide in addition to the existing provisions of the Maritime Code.

Key words: complexity of enforcement on board, direct participants in proceedings, indirect participants in proceedings, procedural actions, incomplete provisions 